\author{
Dr. sc. Marko Ivkošić, \\ docent Pravnog fakulteta Sveučilišta u Splitu
}

\title{
OGRANIČENJE VIŠESTRUKOG I VEĆINSKOG SUDJELOVANJA U PROFESIONALNOM NOGOMETU
}

\author{
UDK: $347.725: 796.332$ \\ DOI: $10.31141 /$ zrpfs.2021.58.139.253 \\ Izvorni znanstveni rad \\ Primljeno: 1. studenog 2020.
}

\begin{abstract}
Za razliku od drugih gospodarskih djelatnosti gdje postoji sloboda ulaganja i stjecanja udjela u drugim društvima na tržištu, u profesionalnom nogometu ona je ograničena. U svim se europskim zemljama bilo zakonski ili na autonomnoj razini zabranjuje horizontalno povezivanje klubova tako da jedan ima utjecaja u drugome i ograničava vertikalni utjecaj jednog ulagača na više klubova. Institut ograničenja višestrukih udjela stožerni je instrument zaštite integriteta i vjerodostojnosti nogometne igre. On odlučujuće utječe na vrsnoću „nogometnog proizvoda“, jer ukoliko postoji mogućnost nečijeg utjecaja na ishod bilo koje utakmice, potkopava se privrženost navijača, zainteresiranost sponzora i medija, a to u konačnici odvraća ulagače od klubova. Nakon raščlambe toga instituta u hrvatskom, njemačkom i autonomnom pravu UEFA-e razmatra se način njegove ispravne primjene u hrvatskom pravu i de lege ferenda daju prijedlozi za njegovu dopunu. Predlaže se i proširiti ustrojbenu mogućnost sportskih klubova na društvo s ograničenom odgovornošću i komanditna društva. To bi, uz ispravnu primjenu instituta ograničenja višestrukih odnosno isprepletenih udjela i podizanja ulagačkog praga na $50 \%$ sudjelovanja u temeljnom kapitalu sportskog dioničkog društva prijelazom kojeg se mora zatražiti dopuštenje za stjecanje dionica, doprinijelo privlačnosti nogometnih klubova kao investicijskih ciljeva.
\end{abstract}

Ključne riječi: višestruki udjeli, kontrola nad društvom, profesionalni nogometni klub, sportsko dioničko društvo, udruga, ograničenje ulaganja

\section{UVOD}

Profesionalni je nogomet od kraja sedamdesetih godina prošlog stoljeća postao sastavnim dijelom gospodarskog života. Posvemašnji prodor medijalalizacije, komercijalizacije i komodifikacije u nogometnu igru potkopavao je potporanj izvorne dogme o pravnoslobodnom prostoru u koji se javne vlasti ne trebaju uplitati. Ne utječući na pravila igre na terenu (lex ludica), nacionalni sudovi kao i Sud Europske unije (nadalje: Sud) ${ }^{1}$ svojim odlukama sve više ulaze u svijet nogometa,

1 Sud Europske unije (eng. European Court of Justice of European Union, njem. Gerichof der Europäichen Union- EuGH) institucija je Europske unije koja obuhvaća: Europski sud pravde/Sud (eng. Court of Justice) i Opći sud (eng. General Court). Više o tome vidi odredbe čl. 251-281 Ugovora o funkcioniranju Europske unije, Službeni list Europske unije, 17. lipnja 2016., 2016/C, 202/01. 
ali onkraj igrališta. ${ }^{2}$ Profesionalni sport, a posebno nogomet, postao je privlačan ulagačima. Klubovi koji su ustrojeni u pravnom obliku trgovačkih društava kapitala bivaju dopadljiv investicijski cilj, što potvrđuje letimični pregled na tržišnu vrijednost udjela u „većim klubovima“, njihove godišnje prihode i dobit, a obrtaj sredstava u gospodarskim djelatnostima koje su izravno povezane s nogometom doseže vrtoglave iznose. Ne treba previdjeti da vrsnoću „nogometnog proizvoda“ uvjetuju sportske pretpostavke ravnopravnosti i neizvjesnosti natjecanja. Sportski se integritet, ultima ratio, brani pravnim normama. U svim europskim zemljama se, bilo zakonski ili na autonomnoj razini, zabranjuje horizontalno povezivanje klubova tako da jedan ima utjecaja u drugome, te se ograničava vertikalni utjecaj jednog ulagača na više klubova. Sprečavanje mogućnosti da jedna fizička ili pravna osoba, samostalno ili djelujući zajednički, stječe udjele u više klubova koji sudjeluju u istom natjecanju važan je potporanj očuvanja integriteta nogometnog sporta. Nakon rasvjetljavanja ključnih pojmova, u radu će se razmatrati pravno uređenje instituta ograničenja višestrukih udjela. Kao stožerni institut integriteta nogometne igre on se u pravilu uređuje autonomnim odredbama nacionalnih nogometnih saveza, a ponegdje i legislativnim instrumentom kojim se uređuju odnosi u sportu, kao što je to slučaj u hrvatskom pravu. Nakon raščlambe relevantnih odredbi Zakona o sportu ${ }^{3}$ (nadalje: ZS), razmotrit će se autonomna pravila europske nogometne konfederacije - UEFA-e, te će se istaknuti posebnosti koje se očituju u propisivanju različitog opsega ograničenja višestrukog sudjelovanja. Uz očuvanje integriteta nogometnog natjecanja putem ograničenja istovremenog sudjelovanja ulagača u više klubova koji sudjeluju u istom natjecanju, u SR Njemačkoj se propisuje i zabrana većinskog sudjelovanja jednog ulagača u temeljnom kapitalu samo jednog društva-kluba. U njemačkoj doktrini poznato kao pravilo „50+1“ razmotrit će se zasebno. ${ }^{4}$ Pravno-politički ciljevi normativnog ograničavanja višestrukog ili većinskog sudjelovanja vanjskih ulagača u nogometnim klubovima su istovjetni. Oba modela služe zaštiti vjerodostojnosti, neizvjesnosti i integriteta nogometnog natjecanja. Međutim, istovremeno se takvim pravilima, koja se ne susreću u drugim gospodarskim djelatnostima, ograničava i/ili otežava tržišno natjecanje među trgovačkim društvima-klubovima, kako na nacionalnoj, tako i na europskoj razini. Prije zaključnih razmatranja raščlanit će se usklađenost navedenih pravila s odredbama europskog prava tržišnog natjecanja. Zadaća je nogometne lex sportiva ublažavati permanentne tenzije i interesne sukobe koji nastaju između autonomnog prava nacionalnih nogometnih saveza, UEFA-e i FIFA-e i heteromonog prava pojedine države, odnosno Europske unije.

2 Po svome je odjeku i utjecaju na razvoj sportskog prava presuda u slučaju Bosman, 12. prosinca 1995., C-415/93, epohalna jer je potaknula lavinu juridičkog propitivanja ispravnosti odluka i pravila koje autonomno donose međunarodni i nacionalni sportski savezi. 98/19.

Zakon o sportu, Narodne novine br. 17/06, 150/08, 124/10, 124/11, 168/12, 94/13, 85/15, 19/16,

4 Posebni oblici zabrane većinskog udjela u temeljnom kapitalu jednog kluba - trgovačkog društva propisuju se još u austrijskom i švedskom sportskom pravu. Više o tome vidi Punte, J. H., Die Kapitalgesellschaft als Rechtform profesionaller Fußballklubs im Spannungsfeld von Verbandsautonomie und Europarecht, OIWIR Oldenburg, 2014., str. 110. i dalje. 


\section{POJMOVNO ODREĐENJE I PRAKTIČNO ZNAČENJE VIŠESTRUKOG I VEĆINSKOG SUDJELOVANJA U PROFESIONALNIM KLUBOVIMA}

U profesionalnom nogometu idealni sportski ciljevi isprepleteni su s profanim materijalističkim ciljevima različitih sudionika. Da težnja za sportskim i financijskim uspjehom ne bi potkopala vjerodostojnost i integritet nogometnog natjecanja, propisuju se koncepti kojima se jednom ulagaču priječi pravo da slobodno, na temelju vlastitih kalkulacija i pobuda, ulaže odnosno preuzima udjele u temeljnom kapitalu različitih klubova - trgovačkih društva, ili da bez ograničenja preuzima udjele u jednom klubu. Ograničenja se mogu svesti na dva pravna instituta koji se skraćeno mogu nazvati ograničenje višestrukog odnosno većinskog sudjelovanja u nogometnim klubovima. U svim europskim državama ograničava se vertikalni utjecaj jednog ulagača na više klubova koji sudjeluju u istom natjecanju i zabranjuje horizontalno povezivanje klubova tako da jedan ima utjecaj u drugome.

Jedna osoba može imati većinski udio u temeljnom kapitalu kluba trgovačkog društva kapitala, ili na temelju obveznopravnih dogovora, utanačenja u organizacijsko-pravnom ugovoru (statutu, društvenom ugovoru) i sl. imati ključni utjecaj na upravljanje i vođenje poslova kluba. Takvu se osobu ograničava u stjecanju udjela u drugim klubovima u istom natjecanju, kako ne bi mogla utjecati na personalnu, sportsku i gospodarsku politiku drugog kluba. Sudjelovanje u drugim klubovima ograničava se, bilo na opseg koji nije dostatan za ostvarenje kontrole nad drugim klubom, bilo da se izrijekom propiše maksimalni postotak njegova udjela u temeljnom kapitalu drugog kluba. Takvo se ograničenje u doktrini naziva višestruko sudjelovanje u društvima kapitala (njem. Mehrfachbeteiligungen an Kapitalgesellschaften eng. Multi-Club Shareholding, Multiple Team Control, Cross-Ownership ili Multi-Club Ownership). ${ }^{5}$ Riječ je o tomu da se osobi koja „kontrolira“ jedan klub ograničava pravo držati udjele u drugome klubu, ali ne apsolutno, već do određene visine ili postotka, pa se za takvo ograničenje može rabiti sintagma ograničenje višestrukih udjela. Kad jedan klub drži udjele u drugom klubu - društvu kapitala onda je riječ o takvoj horizontalnoj povezanosti klubova kakvu se može ostvariti isprepletenim, odnosno uzajamnim udjelima, ali su takvi u profesionalnom nogometu apsolutno zabranjeni. Kako su profesionalni nogometni klubovi u europskim zemljama od osamdesetih godina prošlog stoljeća ustrojeni u pravnom obliku trgovačkih društava kapitala, uz rijetke povijesnopolitički uvjetovane izuzetke, primjerice baskijski klubovi, odredbe o višestrukom sudjelovanju uobičajeno su sročene tako da, prima facie, izgleda da su primjenjive samo na klubove koji se natječu u pravnom obliku trgovačkih društva kapitala. Ali, ograničenje stjecanja ili držanja udjela u temeljnom kapitalu kluba - dioničkog društva ili društva s ograničenom odgovornošću, mutatis mutandis, primjenjuje se na sve sudionike istog natjecanja bez obzira na njihov pravni ustroj i obuhvaća

5 Više o tome vidi Weiler, S., Mehrfachbeteilungen an Sportkapitalgesellschaften, Duncker und Humblot, 2006., str. 27. 
članska prava u trgovačkim društvima osoba, udrugama, kao i u društvima koja se ne susreću u drugim pravnim porecima, primjerice njemačko komanditno društvo na dionice (njem. $K G a A$ ). Općenito se može kazati da se institutom ograničenja višestrukih udjela, onome tko kontrolira jedan klub onemogućava da stječe ili ostvaruje članska prava u drugim klubovima koji sudjeluju u istom natjecanju, na temelju kojih može utjecati na donošenje odluka u tim klubovima.

Ako se ulagačima ograniči mogućnost ostvarenja kontrole ${ }^{6}$ nad klubom društvom kapitala, tako da ne mogu sudjelovati sa više od određenog postotka u temeljnom kapitalu društva, riječ je o ograničenju odnosno zabrani većinskog sudjelovanja (njem. Mehrheitsbeteilungen) koje se u vidu „Pravila 50+1“ primjenjuje u njemačkom nogometu. Taj se institut odnosi samo na klubove koji su ustrojeni u pravnom obliku društva kapitala, jer je nezamislivo da ulagači ulažu u udruge u kojima nemaju imovinskih članskih prava, niti udjela u temeljnom kapitalu društva na temelju kojih se determinira nečija članska moć u društvu, dakle ne može se slobodno raspolagati članskim pravima i sl. Većinsko je sudjelovanje nekog ulagača $\mathrm{u}$ jednom klubu u gotovo svim europskim državama slobodno, a izuzeci postoje u njemačkom, austrijskom i švedskom pravu.

Kao i u drugim gospodarskim područjima, ulagači u trgovačka društva - klubove žele doseći što perspektivniji položaj na (nogometnom) tržištu. Ali u malo kojem području gospodarstva „kapitalizam tako neobuzdano vlada kao u profesionalnom nogometu“" ${ }^{7}$ Za razliku od ostalih gospodarskih područja gdje se lukrativni portfelj može oformiti od udjela u više društava, tako da se ,jaja rasporede u različiti košare“, ulagačima u nogomet se investicijska sloboda značajno sužava. Imatelju udjela u jednom klubu zaprečuje se mogućnost da uopće stječe udjele u drugom klubu ili se određuje postotak do kojeg može stjecati udjele u drugim klubovima. Ukoliko bi se omogućilo pojedinom ulagaču da utječe na donošenje ključnih odluka u trgovačkim društvima-klubovima koji sudjeluju u istom natjecanju, to bi potpuno narušilo nužnu pretpostavku vjerodostojnosti nogometne igre - neizvjesnost ishoda utakmice. Umanjila bi se privrženost navijača, zainteresiranost izravnih i posrednih gledatelja i medija, a to bi posljedično ugasilo luč financijskog erosa ulagača koji poslovično podnose sve osim gubitka. Nogomet je poseban i po tome što klubovi u stvaranju lukrativnog nogometnog proizvoda unutar nogometnih saveza uzajamno surađuju, a istovremeno se na igralištu natječu za pobjedu i stvaraju osobno obilježenu uslugu za gledatelje. Osnovni je cilj svakog trgovačkog društva kapitala dugoročna održivost,

6 Kontrola označava takvo pozicioniranje člana (ulagača) unutar društva na osnovi kojeg se može suvereno upravljati društvom osmišljavanjem i provođenjem organizacijske, poduzetničke i financijske politike društva. Više o tome vidi Meyer, O., Die Übernahme börsennotierter Aktiengesellschaften nach der UE- Übernahmerichtlinie, Hamburg, 2006., str. 72.

7 Ekonomska strana nogometa česta je tema udarnih naslova u tiskanim i elektroničkim medijima, a iznosi koji se uplaćuju prilikom povećanja temeljnog kapitala odnosno nove emisije dionica poznatih klubova, preuzimanja udjela u njima ili iznosi transfernih obeštećenja prelaze milijune ili desetine milijuna eura. Bilo da su uvrštene na neko od kotacija uređenog tržišta vrijednosnih papira ili na tržišne vrijednosti dionica „velikih klubova“ iz Engleske, Španjolske, Italije i Njemačke, nerijetko premašuju astronomski iznos od milijardu eura. Više o tome vidi Galli, A., „Profifußbal-(K)ein Geschäft wie jedes andere?“, Zeitschrift für Sport und Recht, 1/20, str. 19. i 20. 
rentabilnost i stabilnost, a želja za maksimalizacijom profita treba biti usklađena s tim ciljevima. Ostvarenje boljeg rezultata utječe na povoljniji financijski položaj kluba i vice versa, a nerijetko su klubovi usredotočeni na ostvarenje zacrtanog rezultata uz izbjegavanje gubitka odnosno održanje likvidnosti. Kao i druga trgovačka društva, klubovi se mogu financirati vlastitim i tuđim kapitalom. ${ }^{8}$ Osiguranje financijske stabilnosti kao preduvjeta sportske uspješnosti moguce je postići na različite načine. Širok je spektar financijera profesionalnih klubova. Bilo da je riječ o preuzimanju udjela, klupskih obveznica, davanju zajmova ili hibridnom financiranju, nogometni klubovi privlače najrazličitije ulagače. ${ }^{9}$ Učestalo su to trgovačka društva koja se bave medijskom djelatnošću, proizvodnjom sportske opreme i sl., a zanimljivo je da se pored bogatih fizičkih osoba i trgovačkih društava kao ulagači u zapadnoeuropske

8 Vlastiti kapital društva (čista ili neto imovina društva), koji se sastoji od temeljnog kapitala, rezervi društva, neraspoređene dobiti te godišnjeg viška, služi za prvenstveno pokrivanje gubitaka. Umjesto o vlastitom kapitalu (njem. Eigenkapital), može se govoriti o čistoj ili neto imovini društva (njem. Reinvermögen, Nettovermögen) i u literaturi se ti pojmovi koriste kao istoznačnice. Neto ili čista imovina razlika je aktive i obveze, rezervacija i odgođenog plaćanja troškova i prihoda budućeg razdoblja, te rezerva kapitala i rezervi za vlastite poslovne udjele ako ih društvo mora imati. Ulog u društvo (vlastiti kapital) i zajam različitih vrsta i hibridni načini financiranja društva (vanjski kapital) pravno su različiti tipovi kapitala. Vjerovnik na temelju pravnog posla s društvom ima obveznopravni zahtjev na neku činidbu odnosno isplatu, a za korištenje tuđeg novca društvo plaća kamatu koja načelno ne ovisi o tome posluje li društvo s dobiti ili s gubitkom. Članu društva kao ulagaču odnosno davatelju vlastitog kapitala društvu pripada ostatak (njem. Residuum) koji preostane nakon što društvo vjerovnicima ispuni njihove tražbine odnosno isplati dugove, a ne može ga se pravno izjednačiti sa zahtjevom koji vjerovnici imaju prema društvu. Tako Bezzenberger, T., Das Kapital der Aktiengesellschaft, Köln, 2005., str. 14. i dalje.

9 Kao i druga trgovačka društva, nogometni klubovi mogu pribaviti kapital na klasičan način na kapitalnim i kreditnim tržištima, a mogu posegnuti i za alternativnom metodom financiranja koja se kroji prema njihovim potrebama i poslovnim idejama. Tako se, primjerice, klubovi mogu financirati preuzimanjem udjela pri povećanju temeljnog kapitala, zajmovima, izdavanjem obveznica kao i tzv. mezanin kapitalom koji ima obilježja i vlatitog i tuđeg (vanjskog) kapitala. Više o tome vidi Gardt, C., „Moderne Finanzirungsmöglikeiten von Fußballverien der 1. Fußball-Bundesliga“, Zeitschrift für Sport und Recht, 1/15, str. 15. i 16. Moguće je razviti i različite alternativne financijske instrumente koji će se prilagoditi privlačenju navijača koji su emotivno vezani uz „svoj klub“, sponzora kluba, medijske kuće i sl. Alternativni način financiranja uz sudjelovanje navijača i njihovih udruga u našem nogometu primjenjuje se u HNK Hajduk. O sudjelovanju navijača u financiranju i upravljanju u klubu HNK Hajduk vidi više u Ceronja, P., Ivkošić, M., Petrović, S., „Football Club Ownership in the Republic of Croatia: a Model for Suppoters Inclusion in Football Governance in South-East Europe?" u Football and Supporter Activism in Europe, Palgrave Macmillian, 2017., str. 145 i dalje. 
klubove ponekad pojavljuju i pravne osobe javnog prava, pa čak i države. ${ }^{10}$ Osim profita, uobičajenog pokretača poduzetničkih poduhvata, ulagačima su važni i marketinški učinci ulaganja u klubove, pozicioniranje na tržištu i istiskivanje konkurencije, a učestalo je i ulaganje u manje klubove radi lakšeg angažiranja mladih talentiranih igrača. ${ }^{11}$

Ograničenje višestrukih udjela na nacionalnoj razini nije ujednačeno, ali za klubove koji sudjeluju u europskim natjecanjima pod patronatom UEFA-e postoje jedinstvena pravila koja obvezuju sudionike. U nastavku će se odabrati i raščlaniti odredbe o ograničenju višestrukih udjela u hrvatskom pravu i autonomnom pravu UEFA-e, a nakon toga razmotrit će se zabrana većinskog udjela u njemačkom pravu.

\section{OGRANIČENJE VIŠESTRUKIH UDJELA}

\subsection{Općenito}

Od osamdesetih godina prošlog stoljeća profesionalni nogometni klubovi su u gotovo svim članicama Europske unije napustili izvorni pravni ustroj udruge i

10 Uobičajena su medijska izvješća kao, primjerice, „Preijestolonasljednik Saudijske Arabije Mohammed bin Salman uskoro bi mogao postati najbogatiji vlasnik kluba Premier lige i tako preoteti mjesto vlasniku Manchester Cityja, šeiku Mansouru koji je težak 30 milijardi dolara“. Primjerice, financijski ulagač Lars Windhorst je u srpnju 2019. za 40 \% dionica Hertha BSC platio 125 milijuna eura. Više o tome vidi Galli, A., o. c. u bilj. 7, str. 19. i 20. U klubu FC Bayern München AG najveći je imatelj dionica udruga FC Bayern München eV koja drži $75 \%$ dionica, a trgovačka društva AUDI AG, Adidas AG $i$ Allianz SE drže po $8,33 \%$ dionica. Vidi https://fcbayern.com (pregledano 2. travnja 2020.). U srpnju 2017. trgovačko društvo City Football Group držalo je istovremeno udjele u španjolskom klubu FC Giron, engleskom klubu Manchester City kao i u nekoliko nogometnih klubova iz Sjedinjenih Američkih Država, Australije, Japana i Južne Amerike. Više o tome vidi Grell, T., Multy Club Ownership i European Football, Asser Institute, https://asser.institute.nl/sport law/ (pregledano 2. travnja 2020.). Trgovačko društvo $B s k y B$, uvršteno u medijsko carstvo iza kojeg je stajao Rupert Murdoch kojem je osnovna djelatnost proizvodnja i prodaja televizijskog programa i reklamiranje, imalo je istovremeno udjele u nekoliko engleskih klubova: Manchester United $(9,99 \%)$, Chelsa London $(9,99 \%)$, Leeds United $(9,08 \%)$, AFC Sunderland $(4,77 \%)$ itd. Tako je nositelj televizijskih prava u Francuskoj Canal Plus imao udjele u klubovima Servette Genf (52 \%) i Paris St Germain (56 \%). Zanimljivim se čini pokušaj tajlandske vlade da država Tajland preuzme $30 \%$ kluba FC Liverpool. Iako 2004. dionice kluba nisu bile uvrštene na uređeno tržište vrijednosnih papira, Tajland je poslao ponudu u iznosu od 94 milijuna eura za kupnju $30 \%$ dionica kluba koja je nakon javne rasprave i reakcije navijača odbijena. Tajland je ipak uspio preuzeti dionice jednog engleskog kluba - Manchester Cityja, ali ih je 2009. prodao jednom šeiku iz Abu Dabija za 57 milijuna eura. Više o tome vidi Weiler, S. Multy-Club Ownership u Perspektiven des Sportrechts, Berlin, 2005., str. 179. Hovemann, G., „,Die 50+1 Regelung aus sportökonomischer und wettbewerbsrechtlicher Sicht", Zeitschrift für Sport und Recht, 5/2009, str. 189.

11 Nizozemski Ajax je primjer kluba koji ulaže u afričke i južnoameričke klubove s ciljem izravnog novačenja talentiranih igrača u svoje redove ili njihova transferiranja u druge europske klubove. Više o tome vidi Weiler, S., o. c. u bilj. 5, str. 111. i dalje. 
zaodjenuli se u pravno ruho trgovačkih društava kapitala. ${ }^{12}$ Takav pravni odgovor na komercijalizaciju profesionalnog nogometa bila je osnova za propisivanje ograničenja višestrukih udjela u profesionalnim nogometnim klubovima. Naime, samo trgovačka društva kapitala imaju udjele kao neodvojiv splet upravljačkih i imovinskih prava kojima član, načelno, može slobodno raspolagati. Zbog neprofitne prirode udruge, članska su prava u njoj isključivo upravljačke prirode. Kako u njoj nema imovinskih prava, niti kategorije temeljnog kapitala iz koje se oslikava razmjer između uloženog kapitala u društvo i preuzetih članskih prava, udruga nije poželjan ulagački cilj niti je pogodna za ostvarenje poduzetničkih aktivnosti.

U europskim se zemljama višestruki udjeli uređuju posebnim zakonima ili pravilima nacionalnih nogometnih saveza. Tako se, primjerice u Španjolskoj i Poljskoj, kao i u Republici Hrvatskoj, legislativnim instrumentom kojim se uređuju odnosi u sportu propisuje maksimalni iznos višestrukih udjela u iznosu od $5 \%{ }^{13}$ odnosno $1 \%,{ }^{14}$ dok se u Engleskoj, kolijevci profesionalnog nogometa, autonomnim pravilima ograničenje proteže na iznos od $10 \% .{ }^{15} \mathrm{Na}$ temelju monopolno-hijerarhijskog ustroja sporta sudionici europskih natjecanja dužni su se pridržavati pravila UEFA-e kojima se ograničavaju višestruki udjeli. U francuskom i talijanskom nogometu odredbe nacionalnih saveza o višestrukim udjelima sročene su po uzoru na pravila UEFA-e, tako da jedan ulagač, fizička ili pravna osoba ne smije izravno ili neizravno kontrolirati dva ili više klubova niti u njima imati utjecaj na upravljanje ili vođenje poslova. ${ }^{16} \mathrm{~A}$ contrario, ne postavljaju se nikakva ograničenja u smislu ostvarenja utjecaja na ključne odluke u društvu, pa jedna osoba izravno ili neizravno može držati sve udjele u jednom klubu-društvu. Odredbe o višestrukom sudjelovanju ograničavaju osobu koja kontrolira jedan klub, bilo da ostvaruje odlučan utjecaj na donošenje ključnih odluka u (glavnoj) skupštini

12 U engleskom Pramiershipu od 1982., na temelju autonomnih pravila nacionalnog nogometnog saveza, svi profesionalni klubovi (pre)ustrojili su se u pravni oblik trgovačkih društava kapitala, bilo $\mathrm{u}$ oblik dioničkog društva (eng. public limited company - PLC), bilo u oblik društva s ograničenom odgovornošću (eng. private limited company - Ltd). U Francuskoj se Zakonom o organizaciji i poticanju tjelesne i sportske aktivnosti, br. 84-610, 1984. obvezalo profesionalne nogometne klubove ustrojiti u obliku dioničkog društva (franc. la société anonyme) uz dopuštanje iznimki. U Španjolskoj se to učinilo 1992., a klubovi su se morali ustrojiti u pravnom obliku dioničkog društva (španj. la sociedad anónima), uz iznimke, primjerice, baskijski klub Deportivo Bàscio kojem se dopustilo natjecanje u pravnom obliku udruge. U Italiji su se, također, profesionalni nogometni klubovi morali preoblikovati u društvo kapitala, bilo dioničko društvo (tal. societá per azioni, societá - S.A.), ili društvo s ograničenom odgovornošću (tal. societá a risponsabilitá limitata). Od većih europskih država najkasnije se navedeni proces preustroja profesionalnih nogometnih klubova dogodio u SR Njemačkoj. Njemački nogometni savez (njem. Deutsche Fußball Bund - DFB) 1998. donio je odluku, poznatu kao ugaoni vrijednosni papir (njem. Eckwertepapir) na temelju koje se omogućilo dodjeljivanje licence za natjecanje u Bundesligi klubovima koji se ustroje kao trgovačka društva kapitala. Više o tome vidi Weiler, S., o. c. u bilj. 5, str. 77. i dalje. Karch, T., „,Der Fußballbundesligaverein als Wirchaftsunternehmen und Arbeitgeber", Nomos, 2006, str. 144. i dalje.

13 U Španjolskoj je taj iznos ograničen na $5 \%$ (Articulo 23. M. Ley 10/90, de 15 de octubre). Više o tome vidi Punte, J. H., o. c. u bilj. 4, str. 176. i dalje.

14 Ograničenje višestrukih udjela u Poljskoj iznosi $1 \%$. Više o tome vidi Krszesniak, E., J., ,Sports Law in Poland“, Kluwer Law International, 2018. str. 143.

15 Tako Pravila nogometnog saveza prve lige (Football Association Rules of Premier Legaue), Section A: Rule 1.174., a u vezi sa Section I: 1.4., 1.5., 1.6. Vidi https://resources.premierlegaue.com (posjećeno 25. ožujka 2020.).

16 Više o tome vidi Punte, J. H., o. c. u bilj. 4, str. 176. i dalje. 
društva, ili na bilo koji način odlučno utječe na poslovodstvo kluba ili upravljanje, da stječe udjele u drugom klubu. Zaprečuje se jednoj osobi da vertikalno izravno ili neizravno utječe na upravljanje odnosno poslovodstvo u dva kluba (ili više klubova) koji sudjeluju u istom natjecanju. Kontrolu nad društvom treba odrediti u skladu s odredbama nacionalnog prava društava.

\subsection{O autonomiji nogometa}

Piramidalni sustav organizacije suvremenog nogometa omogućuje FIFA$\mathrm{i}^{17}$ ne samo da stvara, primjenjuje i nadzire nogometna pravila, već i da stvara pravo. Autonomno pravo koje FIFA stvara, primjenjuje i nadzire danas je postalo globalno i naddržavno. Nacionalni nogometni savezi kao izravni, a klubovi kao neizravni članovi FIFA-e, na temelju odredbi svojih statuta, moraju primjenjivati propise svjetske i kontinentalne federacije (UEFA) i pod prijetnjom disciplinskih i financijskih sankcija izvršavati naloge njezinih tijela, uključujući i sudbena tijela u nogometu. Međunarodni i nacionalni nogometni savezi stvaraju, primjenjuju i nadziru primjenu pravila kojima se ne uređuju samo sportski, nego i pravni i ekonomski odnosi sudionika u nogometu. Ostvarenje te zadaće postiže se pomoću dvije organizacijsko-kompetencijske pretpostavke: monopolna organizacija nogometa na svjetskoj razini i utvrđivanje obvezujućih pravila što ih donosi krovna nogometna organizacija - FIFA. ${ }^{18}$ Monopolno-hijerarhijski ustroj nogometa omogućuje FIFA-i da donosi obvezujuća pravila, odluke, preporuke, prakse i sl. kojih se moraju pridržavati kontinentalne konfederacije i nacionalni nogometni savezi kao njezine članice. ${ }^{19}$ Načelno se pravila autonomnog sportskog prava

17 FIFA (fran. Fédération Internationale de Football Association) pravna je osoba švicarskog prava sa sjedištem u Zürichu. Kao krovna organizacija donosi obvezujuća sportska, pravna i financijska pravila kojima se moraju podrediti svi nacionalni nogometni savezi, nadzire njihovo provođenje i sankcionira njihove prekršitelje. Članovi su šest konfederacija i 212 nacionalnih saveza. Vidi http://www.fifa.com. (posjećeno 29. ožujka 2020.).

18 Monopolno načelo jednog mjesta za jedan nogometni savez sadrži stvarnu i geografsku sastavnicu. Stvarna sastavnica znači da je za pojedinu vrstu sporta nadležan isključivo jedan savez, a geografska da na određenom državnom teritoriju može biti samo jedan savez. Postoje iznimke kao, primjerice, Ujedinjeno Kraljevstvo. Više o tome vidi Fritzweiler, J., Pfister, B., Summerer, T., Prexishandbuch Sportrecht, München, 1998., str. 10.

19 Čl. 1. st. 3. Statuta FIFA-e. 
mogu podijeliti na pravila saveza - lex sportiva ${ }^{20}$ i sportska pravila - lex ludica. ${ }^{21}$ Pravilima krovnih saveza (FIFA, UEFA i NHS) ${ }^{22}$ uređuju se stručna, prostorna i organizacijska pitanja, pitanja odgovornosti sudionika u nogometu, a po svome ekonomskom i pravnom značaju posebno su važna pitanja uređenja pravnih odnosa između kluba i profesionalnog igrača, transfera profesionalnih igrača, pravnog ustroja klubova i zabrane ili/i ograničenja članstva u klubovima i ulaganja u nogomet. Utvrđivanje, raščlamba i rješavanje navedenih pitanja izazov je s kojim se hvata u koštac sportskopravna judikatura i doktrina. Autonomija krovnih nogometnih saveza u kreiranju, nadzoru i primjeni pravila nogometne igre (lex ludica) gotovo je apsolutna, dok se ona smanjuje ili ograničava kad su u pitanju autonomna pravna pravila nogometnih saveza. Povijesno gledajući, pravo nogometnih saveza nastajalo je i primjenjivalo se neovisno o zapovjednoj moći i prisili državne vlasti. ${ }^{23} \mathrm{Ali}$ komercijalizacija i profesionalizacija nogometa neumitno prouzročava povredu ili ograničenje prava sudionika „nogometnog spektakla“. Povodom traženja pravne zaštite od protupravnog postupanja klubova i nogometnih saveza, rasplinjava se poimanje o apsolutnoj autonomiji nogometnih organizacija i rastače se „dogma o

20 Sustav pravila, odluka i prakse krovnih sportskih saveza koji nastaju samostalno neovisno o državnom pravu u literaturi se naziva lex sportiva, a njezin sadržaj tvore međunarodna autonomna sportska pravila, pa se ona označava i kao međunarodno autonomno sportsko pravo. Lex sportiva se, kao i lex mercatoria, razvijala između privatnopravnih subjekata, na temelju načela privatnopravne autonomije. Obje priznaju kulturne posebnosti i dijelom su pluralističke i kompleksne normativne strukture i obje ističu potrebu za međunarodnim pravnim uređenjem. Više o tome vidi: Gardiner, S., Sports Law, London, 2001., str. 101. i 102., Vieweg, K., Staschik, P., „Lex sportiva und Fairness-Prinzip“, Zeitsschrift für Sport und Recht, 6/2013, str. 227.

Pored dominantnog privatnopravnog stajališta o izvoru i sadržaju lex sportiva, u njemačkoj i američkoj doktrini spominjalo se i međunarodno javnopravno stajalište (Völkerrechtlicher Ansatz) za koje se može kazati da je bilo više prilog raspravi o sportskom pravu koje je danas izgubilo na važnosti. Po toj hipotezi ishodište sportskog prava trebalo je tražiti u pravostvarajućem djelovanju Međunarodnog olimpijskog odbora (nadalje: MOO) kao subjekta međunarodnog javnog prava. Glavni pravni izvori međunarodnog sportskog prava bili bi Olimpijska povelja i statuti međunarodnih sportskih saveza koji su članovi MOO-a. Statut MOO-a ima sličnu pravnu valjanost (änliche Qualität) kao i međunarodni ugovori, pa ga države, čiji su Olimpijski odbori članovi MOO-a, trebaju primjenjivati kao i međunarodne ugovore koji su postali dio nacionalnog javnog poretka. Više o tome vidi: Oschütz, F., ,Sportschidsgerichtbarkeit“", Dunker und Humblot, 2004., str. 351. i dalje.

21 Sportska pravila omogućuju ujednačenost natjecanja u nogometnom sportu stvaranjem jednakih početnih natjecateljskih uvjeta. Njima se uređuju kvalifikacijska i klasifikacijska pitanja, osigurava tjelesni i duševni integritet sudionika, sankcioniraju se ponašanja kojima se povređuju pravila, te se određuju disciplinske sankcije. Pravila kojima se uređuje djelovanje „,na terenu“, primjerice, pravila su o proporcijama terena, trajanju utakmice, širini vratnica, crvenim i žutim kartonima i sl. Više o tome vidi: Hannamann, I., Kartelverbot Verhaltenskoordinationem im Sport, Berlin, 2001., str. 67.

22 Hrvatski nogometni savez (HNS) istovremeno je član kontinentalne konfederacije (UEFA) i FIFA-e. Članovi HNS-a su Županijski nogometni savezi i profesionalni klubovi u skladu s odredbama čl. 46. i 47. ZS-a.

23 O autonomnom pravu općenito vidi Visković, N., ,Državno pravo, autonomna prava i samoupravno pravo“, Arhiv za pravne i društvene nauke, Beograd, 1/1987, str. 3. i dalje. 
neprodornosti ${ }^{\text {“24 }}$ heteronomnog prava unutar autonomnog prava sportskih saveza. ${ }^{25}$ Ne samo da prilikom stvaranja autonomnog prava nogometni savezi moraju poštovati nacionalni pravni poredak, već iz njega crpe glavninu pravnih načela i instituta koji stvaraju smislenu strukturu nogometne lex sportive. Niti sportskih odredbi moraju se utkati u pravnu tapiseriju u kojoj nema previše licencije poetike već su konture strukture i boja unaprijed zadane. ${ }^{26}$ Tako se pojmovi koji se koriste u institutu višestrukih udjela, primjerice udjel u klubu-društvu, prevladavajući utjecaj, poslovodstvo, upravljanje i sl. ne mogu ispravno odrediti, tumačiti niti primjenjivati bez poznavanja prava društava, čija su načela i dogmatika odlučni za razumijevanje navedenog instituta.

\subsection{Ograničenje višestrukih udjela u hrvatskom pravu}

Sedes materiae uređenja višestrukih udjela u našem pravu jesu odredbe čl. 31 . do 36. ZS-a. Profesionalni nogometni klubovi u Hrvatskoj danas mogu biti pravno ustrojeni u obliku udruge ili sportskog dioničkog društva (s.d.d). Adresati navedenih odredbi jesu klubovi koji su ustrojeni u pravnom obliku dioničkog društva kao i fizičke i pravne osobe koje su u statusnopravnoj ili ugovornopravnoj osnovi povezane s klubom. U nakani ostvarenja pravnopolitičkih ciljeva očuvanja vjerodostojnosti, integriteta i neizvjesnosti sportskih natjecanja, prisilnim se propisima utvrđuju dva ograničenja i dvije apsolutne zabrane držanja dionica kluba. U čl. 31. st. 2. ZS-a propisuje se da jedna osoba ne može imati dionice u više klubova - dioničkih društava u iznosu višem od $1 \%$ ukupnog temeljnog kapitala. Takvo ograničenje jednoj osobi koja drži barem jednu dionicu u jednom klubu priječi stjecanje dionica u drugim klubovima iznad propisanog praga. A contrario, jedna osoba može držati dionice u svim klubovima koji se natječu u prvoj i drugoj ligi u iznosu nižem od $1 \%$ ukupnog temeljnog kapitala. Navedeno se ograničenje ne odnosi na pravne osobe javnog prava (Republika Hrvatska, jedinice lokalne i područne samouprave i Grad Zagreb). Ne postoji zapreka da ti subjekti stječu dionice u više klubova koji sudjeluju u istom natjecanju, niti se njima ograničava postotak sudjelovanja u temeljnom kapitalu bilo kojeg kluba. U odredbama čl. 31. st. 4. i 5. propisuju se dvije apsolutne zabrane stjecanja dionica. Adresati prve zabrane jesu „osobe čiji poslovi i djelatnosti mogu neposredno utjecati na sustav natjecanja u odgovarajućem

24 U njemačkoj se literaturi „,dogma o neprodornosti“ naziva Impermebilitätsdogma. V. Hannamann, I., Kartelverbot und Verhaltenskoordinationen im Sport, Berlin, 2001., str. 27.

25 Pozivajući se na slobodu ugovaranja i organiziranja, nacionalni nogometni savezi percipirali su sebe kao subjekte koji se zbog članstva u UEFA-i i FIFA-i ne moraju podvrgavati pod nacionalni pravni poredak, već njihova autonomija predstavlja izvandržavni, od heteronomnog prava oslobođen prostor. Takva se percepcija u potpunosti rasplinjava sredinom devedesetih godina prošlog stoljeća kada Sud Europske unije donosi znamenitu presudu Bosman, 12. prosinca 1995., C-415/93. Da sport ne postane „država u državi, međunarodni sport država pored ostalih međunarodno priznatih država svijeta“, heteronomnim se normama uspostavljaju granice autonomije sporta, pa tako i nogometa. Više o tome vidi Fritzweiler, J., Pfister, B., Summerer, T., o. c. u bilj. 18, 1998., str. 6.

26 Tapiserija je posebna tehnika u kojoj se miješaju likovna i primijenjena umjetnost i zanatstvo, a izrada goblena čisto je zanatski posao bez umjetničke komponente. 
sportu“. Primjerice se navode sportaši, suci, menadžeri i osobe koje su članovi pravnih osoba koje obavljaju djelatnost organiziranja sportskih kladionica. Pored toga zabranjuje se i horizontalno povezivanje klubova u vidu isprepletenih odnosno uzajamnih udjela, tako da klub-s.d.d. ne smije držati dionice drugog kluba u istom natjecanju. Primjenjujući teleološku, sistemsku i ekstenzivnu metodu tumačenja navedene odredbe, ova apsolutna zabrana odnosi se i na klubove-udruge, tako da ni oni ne bi smjeli držati dionice u drugom klubu.

Uz navedeno ograničenje višestrukog sudjelovanja, propisuje se i ograničenje stjecanja značajnog sudjelovanja u temeljnom kapitalu kluba-s.d.d. Dioničari stvaraju volju društva sudjelovanjem i glasovanjem u glavnoj skupštini društva. Pravo glasa jest ovlast dioničara da sudjeluje u stvaranju volje društva donošenjem odluka. ${ }^{27}$ Glasačka je snaga težina koja se u glavnoj skupštini pripisuje dioničaru koji ostvaruje pravo glasa. Ona se mjeri brojem glasova kojima dioničar raspolaže. Kako u društvu članu (drugom društvu) članstvo može imati neko treće društvo koje utječe na stvaranje volje u drugom društvu, izvor stvarne moći u prvom društvu može biti od njega više ili manje udaljen, ovisno o tome koliko je dug lanac sudjelovanja jednog društva u članstvu drugoga, tako da pravilo o odlučivanju samo u uskom okviru formalnih članova može postati iluzijom. ${ }^{28}$ Značajnim se određuje ono sudjelovanje jedne osobe koja izravno, neizravno ili preko povezanih osoba drži dionice na koje otpada više od $25 \%$ temeljnog kapitala. ${ }^{29}$ Naime, imatelj dionica na koje otpada barem $25 \%$ temeljnog kapitala društva zadobiva mogućnost blokiranja svih odluka koje se moraju donijeti tročetvrtinskom većinom, primjerice, odluke o statusnim promjenama, sklapanju poduzetničkih ugovora, povećanju ili smanjenju temeljnog kapitala, izmjeni statuta, opozivu članova nadzornog odbora i sl. Netko može prijeći navedeni prag samo ako za to dobije prethodnu suglasnost Povjerenstva za profesionalne sportske klubove..$^{30}$ Navedenom se odredbom ne zabranjuje stjecanje većinskog udjela u temeljnom kapitalu kluba-s.d.d., ali se to otežava jer svaki ulagač koji smjera postati kontrolni dioničar mora zatražiti suglasnost i Povjerenstvu obrazložiti svoje sportske i gospodarske razloge i planove. Sportski razlozi zaštite vjerodostojnosti i integriteta hrvatskog sporta i pravno-politički razlozi „praćenja“ ulaganja u profesionalne klubove opravdavaju postojanje „kontrole“. Nije uputno klubove potpuno prepustiti „slobodnom tržištu“ jer se može dogoditi da ulagačeve nesmiljene želje za profitom ili rizične odluke mogu dugoročno ugroziti stabilnost kluba. Kontrolni dioničar bi mogao odlukama kojima se povređuju pravna i poslovna pravila i načela destabilizirati klub, primjerice izvlačeći iz kluba likvidnu imovinu ne bi li poboljšao svoje gospodarske prilike i sl. Premda odredbe o povezanim društvima pružaju zaštitu ovisnom društvu, nerijetko se u praksi događa da vladajuće društvo svoje poslovne probleme prenosi na ovisno

27 Više o tome vidi Schmidt, K., Gesellschaftrecht, Carl Heymanns Verlag, 2002., str. 604.

28 Tako Barbić, J., Pravo društava, knjiga prava, Opći dio, Zagreb, 2006., str. 615.

29 Čl. 32. st. 1. ZS-a.

30 Uloga i zadaće Povjerenstva uređene su u čl. 26. ZS-a. Povjerenstvo prilikom odlučivanja mora voditi računa o interesima kluba, sustavu natjecanja u nogometu i posljedicama koje mogu nastupiti ako se uskrati suglasnost (čl. 32. st. 2. ZS-a). 
društvo. Zbog toga u profesionalnom nogometu treba dodatno provjeravati i motive i gospodarsku snagu ulagača ne bi li se umanjila mogućnost da preambiciozni planovi ugroze stabilnost ili opstojnost kluba. Međutim, de lege ferenda predlaže se povisiti prag slobodnog stjecanja dionica kluba-s.d.d. do iznosa od $50 \%$ jer bi se tako olakšalo ulaganje u hrvatski sport, a istovremeno bi se zadržao pregled nad ulagačima kao i mogućnost uskrate suglasnosti za stjecanje dionica iznad toga praga u opravdanim okolnostima. Zakonska je pretpostavka da su osobe povezane: a) ako su se dogovorile usklađeno djelovati, b) ako jedna od njih drži dionice za račun druge i c) ako jedna od njih izravno ili neizravno kontrolira drugu osobu, te da su fizičke osobe u bliskom krvnom ili tazbinskom srodstvu. ${ }^{31}$

Povjerenstvo se mora obavijestiti o svakom stjecanju dionica koje se odnose na najmanje $5 \%$ temeljnog kapitala kluba-s.d.d. ${ }^{32}$ Imatelji glasačkih prava u dioničkom društvu obvezni su obavješćivati o promjenama u postotku glasačkih prava u tome društvu kako bi dioničari, vjerovnici i javnost bili pravovremeno informirani o promjeni stvarnog utjecaja na donošenje odluka u društvu. Time se omogućuje razvidnost članske strukture u slučaju horizontalne povezanosti putem uzajamnih ili isprepletenih udjela, omogućava se uvid u stvarni utjecaj trećih osoba na upravljanje društvom, ali i mogući utjecaj toga društva na druga društva kapitala, tj. umanjuje se mogućnost da nečiji prevladavajući utjecaj u društvu ostane skriven. ${ }^{33} \mathrm{U}$ slučaju protupravnog stjecanja dionica odnosno neobavješćivanja Povjerenstva, propisuje se sankcija u vidu nemogućnosti ostvarenja prava iz svih dionica koje drži u jednom ili više klubova-s.d.d. ${ }^{34}$ Međutim, prava iz tih dionica ne miruju, kao što je to slučaj kod povrede obveze obavješćivanja kod povezanih društava, ${ }^{35}$ već ih je ovlašten ostvarivati povjerenik kojeg je imenovalo Povjerenstvo za profesionalne sportske klubove. Nastupom pravnorelevantnog razloga (protupravnog stjecanja dionica odnosno neobavješćivanja Povjerenstva) dioničar ipso iure gubi upravljačka i imovinska prava iz svih dionica, a članstvo u društvu ostaje mu nedodirnuto jer ne gubi pravo na dionicu. Prava iz dionica jesu pojedinačna prava koja proizlaze iz članstva, pa mogu mirovati ili se prenijeti na povjerenika tako da članstvo ostane nedodirnuto. Povjerenik ostvaruje prava iz dionica sve do trenutka dok se dionice iznad propisanog praga ne otuđe ili, u slučaju neobavješćivanja, dok Povjerenstvu ne stigne propisana obavijest.

Kada je klub kao sudionik nogometnog natjecanja ustrojen u obliku dioničkog društva, on je trgovac i u skladu s odredbom čl. 1. st. 1. ZTD-a on samostalno

31 Čl. 34. st. 1., 2. i 3. ZS-a. Smatra se da netko kontrolira pravnu osobu ako ima izravan ili neizravan većinski udio u temeljnom kapitalu te osobe, ima izravnu ili neizravnu većinu glasačkih prava, ima pravo imenovati ili opozvati većinu članova uprave ili nadzornog odbora ili na neki drugi način može ostvariti prevladavajući utjecaj na tu osobu.

32 Čl. 33. st. 1. i 2. ZS-a.

33 Više o tome vidi Ivkošić, M., ,Gubitak prava glasa - sankcija zbog povrede odredbi o obavješćivanju odnosno preuzimanju dioničkih društava“, Zbornik 55. susreta pravnika, Opatija 2017., str. 348.

34 Arg. ex 35. i 36. ZS-a.

35 Arg. ex 478. st. 6. Zakona o trgovačkim društvima, Narodne novine br. 111/93, 34/99, 121/99-vjerodostojno tumačenje, 52/00- - Odluka Ustavnog suda RH, 118/03, 107/07, 146/08, 137/09, 125/11, 111/12, 68/13, 110/15, 40/19. (dalje: ZTD). 
i trajno obavlja gospodarsku djelatnost na tržištu. Odredbama ZS-a propisana ograničenja i zabrane stjecanja udjela u klubu-s.d.d. nisu uobičajena u drugim područjima gospodarstva. Posebnost nogometa i sporta općenito opravdani je razlog ograničavanja ili onemogućavanja jedne osobe, i s njom povezanih osoba, da steknu značajnije udjele u više klubova ili ostvare prevladavajući utjecaj u jednom klubu. Međutim, s motrišta prava tržišnog natjecanja nameće se pitanje mogu li se legitimni ciljevi očuvanja vjerodostojnosti, kontinuiteta i neizvjesnosti nogometnog natjecanja ostvariti i mjerama koje su za ulagače manje ograničavajuće nego li je to sada slučaj, a o tome će se raspravljati u petom poglavlju rada.

\subsubsection{Primjenjuju li se odredbe o ograničenju višestrukih odnosno isprepletenih udjela i na klubove-udruge?}

Promatrajući usporednopravna rješenja, nisko propisani prag višestrukih udjela u iznosu od $1 \%$ rijedak je i postoji samo iznimno, primjerice u Poljskoj, ${ }^{36}$ dok u Njemačkoj i Engleskoj iznosi 10 \%, a u Italiji, Francuskoj i većini država članica Europske unije navedeni postotak doseže razinu do koje se može ostvarivati kontrola nad društvom. ${ }^{37}$ Propisi autonomnog prava nogometnih saveza kojima se uređuju instituti višestrukih udjela često su sročeni po uzoru na pravila UEFA-e (pravila o natjecanju sadrže odredbe koje su naslovljene „Integrity of competition“) po kojima kontrolni dioničar ili imatelj udjela u jednom klubu ne smije držati većinu dionica ili udjela s pravom glasa u drugom klubu ili na bilo koji način ostvarivati odlučujući utjecaj na donošenje odluka u drugom klubu koji sudjeluje u istom natjecanju. Netko tko ostvaruje prevladavajući utjecaj u jednom klubu smije stjecati udjele u drugim klubovima samo do praga koji se u nacionalnom pravu društava može označiti

36 Prema poljskom zakonu kojim se uređuju odnosi u sportu, osoba koja izravno ili neizravno kontrolira jedan klub ne smije držati više od $1 \%$ dionica u drugim klubovima koji sudjeluju u istom natjecanju. Više o tome vidi Krszesniak, E., J., „Sports Law in Poland“, Kluwer Law International, 2018. str. 143.

37 Od značajnijih profesionalnih nogometnih liga manji postotak od toga postoji u Španjolskoj. Imatelj većinskog udjela u jednom klubu u Španjolskoj može stjecati dionice u drugim klubovima do visine od $5 \%$. Posebnost je njemačkog prava da nitko tko izravno ili neizravno drži iznad $10 \%$ udjela u pravu glasa ili kapitalu jednog društva-kluba ne smije imati udjele u drugim klubovima-društvima koji sudjeluju u istom natjecanju. A nitko ne smije držati udjele u više od tri kluba. O tome vidi u bilj. 13, 14. i 15., a u nastavku rada detaljnije će se raspravljati o ograničenju višestrukih i većinskih udjela u njemačkom pravu. 
kontrolnim. ${ }^{38}$ Nije lako odrediti pod kojim pretpostavkama neki dioničar može ostvariti kontrolu na glavnoj skupštini društva, tj. ostvaruje li apsolutnu ili relativnu kontrolu. Apsolutnu kontrolu nad društvom može ostvariti dioničar, koji samostalno ili djelujući zajednički, drži više od $50 \%$ dionica, dočim je određenje relativne kontrole nad društvom ovisno o konkretnim okolnostima. Utjecaj dioničara ne ovisi samo o broju dionica s pravom glasa koje on drži, već i o opsegu sudjelovanja ostalih dioničara na glavnoj skupštini društva, raspršenosti dioničara i njihovoj strukturi, stupnju dioničarske suradnje i sl.

U većini je europskih država ograničenje višestrukih udjela uređeno autonomnim pravom nogometnih saveza, dok je kod nas ono uređeno zakonom kojim se općenito uređuju odnosi u sportu. Zbog prisilne prirode odredbi čl. 31. do čl. 36. ZS-a kojima se uređuju modeli višestrukog (vertikalnog) $\mathrm{i}$ isprepletenog ili uzajamnog (horizontalnog) sudjelovanja u temeljnom kapitalu kluba-s.d.d., zakonodavac je zacrtao granice ili, bolje reći, suzbio autonomiju sportskih saveza da samostalno urede tu materiju. Autonomnim pravom moguće je samo postrožiti zakonsko rješenje, ukoliko nacionalni savez dotičnog sporta drži prikladnim dodatno zaštititi vjerodostojnost i integritet natjecanja, ali ga se ne smije ublažavati. Ozbiljan je problem hrvatskog profesionalnog nogometa činjenica da su navedene odredbe sročene tako da se, prima facie, primjenjuju samo na klubove koji su ustrojeni u obliku s.d.d., premda se u prvoligaškom natjecanju pojavljuju i klubovi koji su zadržali izvorni pravni oblik udruge. Ta dva pravna oblika uređena su različitim legislativnim instrumentima, imaju različita obilježja, unutarnji ustroj i ciljeve. Uočljiv je sinkretizam između neprofitnosti udruge, njezine osnovne differentie specifica spram trgovačkih društava, i profesionalnosti nogometnih klubova. Jesu li udruge zaista izvan dosega odredbi o višestrukim udjelima? Odredbe su precizno naslovljene (čl. 31. „Članstvo u dioničkom društvu“...) i jasno sročene pa se jezičnim i logičnim tumačenjem dade zaključiti da su njihovi adresati samo klubovi ustrojeni kao s.d.d. i osobe izravno ili neizravno povezane s tim klubovima. Kako nema odredbe kojom se izrijekom upućuje da se navedene odredbe primjenjuju i

38 Pojam kontrole nad društvom rabi se u našem pravu preuzimanja, pravu tržišnog natjecanja i sportskom pravu, dok se sintagma ,prevladavajući utjecaj“ udomaćila u hrvatskim propisima kojima se uređuju unutarnji odnose u dioničkom društvu, primjerice odredbe o povezanim društvima. Sintagma „kontrola nad društvom“ preuzela se iz anglosaksonskog prava prilikom uređenja postupka preuzimanja dioničkih društava. Obveza objavljivanja javne ponude uvodi se u naše pravo 1997. donošenjem Zakona o postupku preuzimanja dioničkih društava, koji zamjenjuje drugi po redu Zakon iz 2002., a danas je na snazi treći Zakon o preuzimanju dioničkih društava, Narodne novine, br. 109/07, 36/09, 108/12, 90/13, 99/13, 147/13. u kojem u nizu odredbi koriste termin „kontrola“, „kontrolni prag“ i sl. U odredbama čl. 12. i 15. Zakona o zaštiti tržišnog natjecanja, Narodne novine br. 79/09, 80/13 za unutarnje odnose u ,poduzetniku“ rabi se naziv „,kontrola“, dok se sintagma ,prevladavajući utjecaj“ rabi za određenje postotka udjela na tržištu, a ne za determiniranje unutarnjih odnosa u društvu. U odredbi čl. 34. st. 2. ZS-a također se slijedi anglosaksonska terminologija u određenju pretpostavki kada osoba ,kontrolira drugu pravnu osobu“. Činom preuzimanja kontrole nad društvom novi kontrolni dioničar zadobiva moć da mijenja poduzetničku, organizacijsku i personalnu politiku društva. Dosezanje glasačke snage u glavnoj skupštini društva kojom se može ostvariti kontrola nad društvom sama je po sebi i samostalna gospodarska vrijednost, za što su novi kontrolni dioničari spremni platiti i posebnu premiju, tj. iznos veći od tržišne cijene dionice. Više o tome vidi Brnabić, R., Ivkošić., M., „Novine u pravu preuzimanja dioničkih društava“, Zbornik 52. susreta pravnika, Opatija, 2014., str. 93. i dalje. 
na klubove-udruge, pitanje je ostaju li udruge izvan dosega tih odredbi i mogu li se one na različite načine horizontalno povezivati i uzajamno utjecati na sportske $\mathrm{i}$ financijske rezultate, ili može li jedna osoba izravno ili neizravno vertikalno utjecati na oblikovanje volje u dvije ili više udruga-klubova. Ako takva mogućnost nije izrijekom zakonom zabranjena, može li se ona dopustiti na temelju privatnopravnog načela slobode uređivanja obveznih odnosa? ${ }^{39}$ Ako bi to bilo moguće, kluboviudruge mogu neformalno surađivati, ili neka fizička ili pravna osoba može utjecati na barem dva kluba-udruge, a sve u cilju boljih sportskih i/ili financijskih rezultata tih klubova ili osoba. Neumitni ishod mogućnosti takvog djelovanja, a kamoli njegovo ostvarenje, jest povreda temeljnih sportskih i moralnih načela. Dokidanje vjerodostojnosti, integriteta i neizvjesnost nogometnog natjecanja ne potkopava samo ljepotu nogometne igre i vrsnoću natjecanja, već i utrživost „nogometnog proizvoda“. Takav, očito razoran, učinak na profesionalni nogomet pokušao se zapriječiti na temelju odredbe čl. 27. st. 3. ZS-a. Članovi tijela kluba-udruge, osobe ovlaštene za njegovo zastupanje ili vođenje poslova ne mogu imati takav položaj $\mathrm{u}$ drugom klubu-udruzi koji se natječe $\mathrm{u}$ istom sportu, a to ne mogu biti niti osobe koje svojim djelovanjem mogu utjecati na sustav natjecanja. Je li se navedenom odredbom popunila praznina glede ograničenja višestrukih i isprepletenih udjela kod udruga, tj. zabranjuje li se time jednoj fizičkoj ili pravnoj osobi da izravno ili neizravno, samostalno ili djelujući zajednički vertikalno ostvaruje utjecaj na stvaranje volje u barem dva kluba-udruge, odnosno je li se time apsolutno zabranilo bilo kakvo horizontalno povezivanje udruga? Nažalost, odgovor je negativan. Navedenom se odredbom ne uređuje materija višestrukog odnosno uzajamnog sudjelovanja kao što je to slučaj kod s.d.d., već se njome, per se, određuje samo koja osoba ne smije biti član tijela udruge-kluba, ili osoba ovlaštena za njezino zastupanje odnosno vođenje poslova. Tom se odredbom samo refleksno utječe na ograničenje horizontalnog i vertikalnog povezivanja i to u slučaju kad udruga, ili osoba koja izravno ili neizravno može utjecati na stvaranje njezine volje, drži udjele u temeljnom kapitalu kluba-s.d.d. i vice versa, ukoliko je klub-s.d.d., ili osoba koja ima prevladavajući utjecaj u tome s.d.d.-u, član kluba-udruge odnosno tijela udruge. Međutim, na temelju te odredbe nije moguće protegnuti doseg odredbi čl.31. do 36. ZS-a na slučajeve suradnje dvaju klubova-udruga, ili kada jedna fizička ili pravna osoba istovremeno izravno ili neizravno utječe na sportsku i/ili financijsku politiku dva kluba-udruge.

Može li se u autonomnom sportskom pravu pronaći pravilo kojim se može ispuniti navedena praznina? Naime, cjelokupno autonomno pravo HNS-a, UEFA-e i FIFA-e ima prednost pred državnim dispozitivnim pravom na temelju načela lex specialis derogat legi generali. U većini europskih zemalja odnosi u sportu uređuju se posebnim legislativnim instrumentom, a istovremeno se autonomnim pravom nogometnih saveza dodatno uređuju važna pitanja, pa se, primjerice, institut višestrukih udjela uređuje pod egidom očuvanja integriteta natjecanja. Postoje li

39 Arg. ex čl. 2. Zakona o obveznim odnosima, Narodne novine, br. 35/05, 41/08, 125/111, 78/15, $29 / 18$. 
takva pravila unutar autonomnog prava koje stvara HNS? Kao član UEFA-e i FIFA-e, HNS se na temelju odredbe o podvrgavanju čl. 11. Statuta HNS-a obvezao podvrći pod sva pravila FIFA-e i UEFA-e, pa je bilo očekivano da će po uzoru na autonomno pravo tih organizacija i HNS-ov Pravilnik o nogometnim natjecanjima ${ }^{40}$ sadržavati odredbe o integritetu natjecanja. Međutim, on ne sadrži takve odredbe i ne obvezuje sudionike natjecanja da prikažu je li fizičke i pravne osobe koje utječu na jedan klub imaju utjecaj u stvaranju volje u drugim klubovima. Jedino se u dodatku HNS-ovog pravilnika o licenciranju u dijelu IV. naslovljenom „Pravni kriteriji“ nalaže klubu - tražitelju licencije da razvidno „grafički prikaže svoju pravnu strukturu“, a taj prikaz mora sadržavati sve pravne i fizičke osobe koje mogu utjecati na oblikovanje volje kluba, neovisno radi li se o klubu-udruzi ili s.d.d.- $\mathrm{u}^{41}$ Pravilnik nije ispravno sročen i nazivlje u njemu nije u duhu hrvatskog pravnog izričaja, pa se umjesto članskih prava u društvu koriste sintagme „,izravno ili neizravno vlasništvo" u klubu, ,vlasnički interes“ i sl., ali se iz njega dade iščitati da klub mora iskazati svoju člansku i upravljačku strukturu, a naročito je obavezno poštovati naputak - ,dužni označiti osobu koja je na bilo koji način uključena ili ima bilo kakav utjecaj na upravljanje financijskim ili poslovnim politikama kluba“. Ta autonomnim pravom utvrđena dužnost kluba - tražitelja licencije ne može poslužiti kao relevantna odredba za popunjavanje zakonske praznine, jer se njome ne uređuje ograničenje višestrukog sudjelovanja niti zabrana isprepletenih udjela u klubovimaudrugama. Na temelju nje davatelj licencije - HNS, ipak, ima uvid u članske i upravljačke strukture svih klubova koji su zatražili licenciju i presumtio iuris jest da HNS zna ili bi morao znati tko upravlja pojedinim klubom i kada je na bilo koji način osoba koja kontrolira jedan klub kadra ostvarivati utjecaj na donošenje odluka u drugom klubu. Zakonsku prazninu nije moguće ispuniti niti odredbama kojima se uređuju višestruki udjeli u natjecanjima koja organizira UEFA, ${ }^{42}$ jer se tiču europskih natjecanja, a ne nacionalnog prvenstva.

40 Pravilnik o nogometnim natjecanjima objavljen je u Glasniku HNS-a 24/07 - pročišćeni tekst, 09/08, 23/08,9/09, 10/09 - ispravak, 23/09 - pročišćeni tekst,10/10, 15/11, 46/11, 56/11, 19/12, 22/12, 23/12 - ispravak, 28/13, 09/14, 15/14, 60/14, 34/15, 28/16, 51/16,05/17,45/17,37/18,55/18, 22/19,29/19 i $09 / 20$.

41 Na str. 60. priloga Pravilnika o nogometnim natjecanjima traži se od kluba - tražitelja licencije da grafički prikaže pravnu strukturu: „Prikaz pravne strukture tražitelja licencije mora jasno prikazivati i sadržavati informacije o tražitelju licence, a osobito sastav i način popunjavanja skupštine, te popis članova tijela tražitelja licence, te informacije o pravnoj strukturi grupe: svakom ovisnom subjektu, podružnici tražitelja licence, svakom subjektu koji ima izravnu ili neizravnu kontrolu nad tražiteljem licence sve do i uključujući krajnju stranu koja ga kontrolira, svakom pridruženom subjektu, svakoj strani koja ima $10 \%$ ili više izravnog ili neizravnog vlasništva tražitelja licence, ili koja ima $10 \%$ ili više glasačkih prava u tražitelju licence, o svakoj strani koja ima značajan utjecaj nad tražiteljem licencije, o bilo kojem nogometnom klubu u odnosu na koji bilo koja strana navedena u prethodnim točkama, ili bilo koji član njihove ključne uprave ima bilo kakav vlasnički interes, pravo glasa i/ili je na bilo koji način uključen ili ima bilo kakav utjecaj na upravljanje njegovim financijskim ili poslovnim politikama. Za svaki od gore navedenih subjekata koje je tražitelj licence uključio u opseg izvještavanja, mora Davatelju licence dostaviti sljedeće informacije: naziv pravnog subjekta; vrstu pravnog subjekta; informacije o glavnim djelatnostima; \% vlasničkog interesa (ukoliko je različito: \% prava u odlučivanju); udio u kapitalu; ukupnu imovinu; ukupne prihode i ukupni kapital.“

$42 \mathrm{O}$ institutu višestrukih udjela u autonomnom pravu UEFA-e raspravljat će se u nastavku rada. 
U nedostatku prikladne odredbe autonomne nogometne lex sportiva, navedenu pravnu prazninu treba popuniti sadržajem koji pruža ordre public. Sloboda stvaranja prava koje se razlikuje od dispozitivnih odredbi državnog prava nužan je uvjet postojanja autonomnog prava nogometnih organizacija. Ali autonomno pravo HNS-a nema vlastitu metodologiju, načela i institute i nužno mora biti uklopljeno u hrvatski pravni poredak i oslonjeno na njega. Odredbe sportskog (nogometnog) prava treba tumačiti na temelju metoda koje su imanentne hrvatskom pravu, i njihova se primjena mora oslanjati na postojeću infrastrukturu koje pruža naše pravo. „Normativno oblikovana predkoncepcija“43 nacionalnog prava spasonosno je sredstvo ne samo tumačenja i primjene prava u sportu, već je to i sredstvo popunjavanja pravnih praznina. A contrario, u sportu bi se učestalo pojavljivale prave aporije, koje bi podjarivale vladavinu prava. Za svaku povredu subjektivnih prava, pa tako i prava sudionika nogometnog natjecanja na ravnopravni tretman, pravni poredak mora iznaći rješenje. U nedostatku izričitog upućivanja da se instituti višestrukog (vertikalnog) i uzajamnog odnosno isprepletenog (horizontalnog) sudjelovanja u klubovima koji su pravno ustrojeni kao s.d.d. primjenjuju i na udruge, pojavila se pravna praznina koju treba, in ultima linea, popuniti pozivajući se na temeljna pravna načela, koja su konačna utočišta, ne samo za tumačenje prava već $i$ za popunjavanje pravnih praznina. Pored tradicionalnih sportskih načela, sudionici u profesionalnom nogometnom natjecanju moraju se pridržavati i općih pravnih načela, a posebno onih obveznopravnih i načela prava društava. Jer ako nema pravne i faktične ravnopravnosti sudionika-natjecatelja, njihova fer-nadmetanja na terenu, ali i izvan njega, ako se ne poštuje načelo savjesnosti i poštenja ili se vrijeđa načelo prava društava da pod jednakim uvjetima svi članovi imaju jednaki položaj u društvu, ili da se svi klubovi neovisno o pravnom obliku ravnopravno tretiraju i ograničenja koja vrijede za s.d.d. vrijede i za udruge i sl. - nije moguće osigurati vjerodostojnost, kontinuitet ni neizvjesnost natjecanja. Zbog toga bi institute ograničenja višestrukih udjela odnosno zabrane isprepletenih udjela u udrugama trebalo promatrati kao prešutni koncept koji izvire iz same biti nogometnog sporta. Radi osiguranja ustavnopravne jednakosti sudionika nogometnog natjecanja i ostvarenja temeljnih ciljeva profesionalnog nogometa sadržaj instituta višestrukih odnosno isprepletenih udjela koji se primjenjuju na s.d.d. treba na primjeren način primijeniti na klubove-udruge. Apsolutnu zabranu isprepletenih ili uzajamnih udjela treba tumačiti tako da ni jedan klub-udruga ne smije biti u mogućnosti izravno ili neizravno ostvarivati utjecaj na donošenje odluka u drugom klubu bez obzira na njegov pravi ustroj. Ograničenje višestrukih udjela treba tumačiti tako da osoba koja izravno ili neizravno ima utjecaj u jednom klubu (s.d.d.-u ili udruzi) ne smije imati nikakav utjecaj u drugom klubu-udruzi. Naime, dioničar koji ima dionice koje se odnose na $1 \%$ temeljnog kapitala nema nikakav upravljački utjecaj u tom društvu

${ }^{43}$ Autonomna pravila sportskih saveza utemeljena su na „normativno oblikovanoj predkoncepciji“ (eng. normativly shaped preconception) tako da imaju prednost u primjeni od dispozitivnih odredbi heternonomnog prava. Ali nacionalno pravo daje načela, metodologiju i cijelu infrastrukturu za tumačenje i primjenu autonomnog sportskog prava. Više o tome vidi Haas, U., „Applicable Law in football-related dispites - The relationship between the CAS Code, the FIFA Statutes and the agreement of parties on the application of national law", CAS Bullettin, 1/15, str. 15. i 16. 
ukoliko se ne poveže s drugim dioničarima. A simili ad simile osoba koja kontrolira jedan klub ne bi uopće smjela imati ikakav izravni ili neizravni utjecaj u drugom klubu-udruzi.

Kao davatelj licencije, HNS je dužan ex officio provjeriti postoji li okolnost da jedna fizička ili pravna osoba ima bilo kakav utjecaj na upravljanje financijskim ili poslovnim politikama kluba, neovisno radi li se o klubu ustrojenom u obliku s.d.d.-a ili udruge. Postoje li pritužbe ostalih klubova, koji se natječu u prvoj nogometnoj ligi, da postoji visoka razina vjerojatnosti kako se kod dvaju udruga povređuju prisilne odredbe o ograničenju višestrukih odnosno isprepletenih udjela, ili da neka osoba ima utjecaj na oblikovanje volje i vođenje poslova u dva kluba koji sudjeluju u istom natjecanju, HNS je bio dužan reagirati, izvršiti sve relevantne provjere i izvijestiti o tome sve sudionike natjecanja. Ako postoji bilo koja indicija da se miješaju imovine dvaju klubova ili se oni sportski potpomažu ili uzastopce ustupaju igrače ili neka druga (sportska) prava, ili neka osoba izravno ili neizravno utječe na njihovo upravljanje i/ili poslovodstvo, HNS je dužan takve prakse sasjeći u korijenu. Štiteći vjerodostojnost prvoligaškog natjecanja, vlastiti integritet $i$ integritet ostalih sudionika natjecanja, mora se takvim osobama ili klubovima dati primjeren rok da prestanu s takvim protupravnim djelovanjem, a u konačnici i uskratiti licenciju. Takva i slična postupanja ne spadaju samo u sferu nelojalne konkurencije već su suprotna pravilima morala društva pa su, inter alia, i zbog toga protupravna. Čitatelju koji i periferno prati hrvatski nogomet lako je odgonetnuti koja su dva kluba u prvoj nogometnoj ligi prisno povezana. Iz minuciozno razrađene analize njihovih sportskih i ekonomskih odnosa vidljivo je da dva sudionika prve nogometne lige opetovano povređuju prisilne zakonske odredbe o višestrukim odnosno isprepletenim udjelima, načela nogometnog sporta, načela sportskog autonomnog prava kao i načela obveznog prava i prava društava, i to bez ikakvih sankcija. ${ }^{44}$ Nezakonita i sportskom fer natjecanju protivna praksa o kojoj se već godinama raspravlja u sportskoj javnosti pokušala se zaustaviti unutar nogometne organizacije, ali bez uspjeha. ${ }^{45} \mathrm{HNS}$ uporno zanemaruje važnost teme i proglašava se nenadležnim ulaziti u unutarnje odnose u pojedinim klubovima. Ali, to nikako ne smije biti izlika za zaobilaženje skrbi o vjerodostojnosti i integritetu prvoligaškog natjecanja. A contrario, na prvu obrazloženu primjedbu o horizontalnoj povezanosti klubova ili nečijem vertikalnom utjecaju na više klubova HNS je bio dužan primijeniti prisilne odredbe o zabrani vertikalnog utjecaja na više klubova. A ako nije bio kadar riješiti prijepornu situaciju ispravnim popunjavanjem pravne praznine i prisilne odredbe ograničenja višestrukog i uzajamnog odnosno isprepletenog sudjelovanja na prikladan način primijeniti na udruge, bio je dužan u svoje autonomno pravo, primjerice u Pravilnik o nogometnim natjecanjima,

44 Više o tome vidi Globan, T., Jägers, E., „Multiple Ownership, collusion end unusual result; patterns in soccer", Contemporary Economic Policy, Vol. 37, 2019., str. 245. i dalje. Dostupno na https:// onlinelibrary.wiley.com/doi/full/10.1111/coep.12286 (pregledano 15. travnja 2020.).

45 HNK Hajduk je 2015. pokušao s obrazloženim zahtjevom osporiti izdavanje licencije NK Lokomotivi za sudjelovanje u prvoj hrvatskoj nogometnoj ligi. HNS je odbio zahtjev, zanemarujući kako prisilne odredbe ZS-a o ograničenju višestrukih udjela, odnosno zabrani bilo kakvog uzajamnog utjecaja sudionika u istom natjecanju, tako i načela obveznog prava i prava društava. 
impostirati odredbe o integritetu natjecanja i time zaustaviti daljnje zaobilaženje prava i ugrozu vjerodostojnosti i integriteta prvoligaškog natjecanja. Začudno je da on dodjeljuje licencije (dopuštenje za sudjelovanje u natjecanju) i ima uvid u pravnu, ekonomsku i sportsku „krvnu sliku“ natjecatelja i ne vidi nikakav problem u povezanosti dvaju zagrebačkih klubova. Bilo je dovoljno, bez istraživanja financijske i personalne povezanosti, pogledati prijelaz igrača iz jednog u drugi klub ili njihove uzajamne rezultate i sl. da se utvrdi da postoji povezanost koja šteti prvoligaškom natjecanju. Sportska, ekonomska i personalna povezanost udruga GNK Dinamo i NK Lokomotiva bila je lani predmetom obrade jednog znanstvenog rada s područja ekonomije, u kojem se s uvjerljivim razlozima brani teza da je prisnost nedopustiva jer izravno utječe na uzajamne rezultate, a to se ponekad odražava na konačni ishod nogometnog prvenstva. ${ }^{46}$

HNS je dužan bdjeti nad profesionalnim nogometom, osiguravati regularnost natjecanja i ne dopuštati da klubovi-udruge budu u povlaštenijem položaju od klubova ustrojenih kao s.d.d., pa tako i po pitanju primjene instituta višestrukih odnosno isprepletenih udjela. HNS ne raspetljava taj gordijski čvor profesionalnog nogometa i izbjegava ostvarivati svoju sportsku i pravnu zadaću osiguranja ravnopravnosti prvoligaškog nogometnog natjecanja, a od UEFA-e se ne može očekivati da skrbi o dobrobiti hrvatskog nogometa i sređuje stanje u njemu, jer za to nije ovlaštena. U takvoj su situaciji, radi zaštite pravno-političkih ciljeva osiguranja integriteta i vjerodostojnosti nacionalnog prvoligaškog natjecanja, i radi osiguranja vladavine prava, dužne reagirati državne institucije, a u prvom redu Središnji državni ured za šport. ${ }^{47}$ Već se dugo čeka ispravna, cjelovita i svrhovita reakcija nadležnih sportskih i državnih tijela koja je nužna za povratak vjerodostojnosti profesionalnog nogometa i integriteta prvoligaškog natjecanja. Pa zar je tako teško na primjeren način primijeniti odredbe o ograničenju višestrukih odnosno zabrane isprepletenih

46 Odnos između dvaju zagrebačkih klubova, GNK Dinama i NK Lokomotive, neprekidno uzburkava strasti u hrvatskom nogometu još otkako je NK Lokomotiva 2009. godine ušla u 1. HNL, gdje se natječe s GNK Dinamom. Razlog tomu su tvrdnje o bliskoj povezanosti u sportskim i poslovnim poduhvatima između dva kluba i (ne)izravnoj financijskoj i kadrovskoj ovisnosti Lokomotive o Dinamu. Dovodeći u pitanje samu regularnost 1. HNL, HNK Hajduk je 2015. podnio zahtjev prema Hrvatskom nogometnom savezu (HNS) da Lokomotivi ne izda licenciju za nastup u 1. HNL. Obrazlažući svoj zahtjev, Hajduk je, između ostalog, naveo da je čak 50-70 \% igrača koji su u razdoblju od sezone 2009./10. do 2013./14. nastupili za Lokomotivu, u nekom trenutku svoje karijere bili članovi i registrirani igrači GNK Dinamo. Pokazalo se da se nijedan odnos dvaju klubova u ligi ne može usporediti s brojem privremenih transfera (posudbi) i transfera igrača kao onaj između Lokomotive i Dinama. Broj privremenih transfera igrača između ovih dvaju klubova uvelike nalikuje uzorku koji se uobičajeno nalazi između A i B ekipa istoga kluba. Pozornijim pratiteljima domaćeg nogometa vjerojatno je poznato da je Lokomotiva u prvih 27 utakmica protiv Dinama ubilježila 0 pobjeda, 1 remi i 26 poraza. Takav slab učinak zvuči neobično i rezultatski podbačaj je (ne)vjerojatan. Pitanje je postoji li ijedan drugi par klubova u ligi koji se barem približno može mjeriti s ovakvim uzorkom rezultata. Rezultati su, nažalost, poražavajući i izvjesno je da postoji bliska povezanost između ta dva kluba. Više o tome vidi Globan, T., Jägers, E., o. c. u bilj. 44, str. 246. i dalje.

47 Središnji državni ured za šport dužan je izravno ili putem Povjerenstva za profesionalne sportske klubove nadzirati zakonitost rada nacionalnih saveza. Dogma o neprodornosti državnog prava $u$ profesionalni sport urušila se prije više od tri desetljeća. Državna tijela nadležna za sport i sudovi dužni su djelovati uvijek kada je sustav narušen odnosno kada se povređuju prisilne zakonske odredbe kojima je cilj osigurati vjerodostojnost, integritet i neizvjesnost sportskih natjecanja. 
udjela na klubove-udruge i otvoriti dodatni prostor razvoju hrvatskog profesionalnog nogometa? Nije moguće sportskim, ekonomskim niti pravno-političkim razlozima opravdati „nojevski“ pristup neuralgičnom problemu hrvatskog profesionalnog nogometa, koji, nažalost, prerasta granice moralnog i pravnog normativnog poretka i prerasta u društveni problem, a podgrijavajući podjele služi i protudržavnom interesu podrivanja jedinstva hrvatskog nacionalnog bića.

Navedeni se institut dosljedno primjenjuje na sve sudionike istog natjecanja bez obzira na njihov pravni ustroj, kako na razini europskih natjecanja u organizaciji UEFA, tako i na razini nacionalnih natjecanja što ih organiziraju nacionalni nogometni savezi. Za razliku od toga, institut većinskog sudjelovanja u temeljnom kapitalu kluba-društva tiče se samo klubova koji su ustrojeni u pravnom obliku trgovačkih društava kapitala. Razumljivo je da se na udruge u kojima se demokratski odlučuje po načelu ,jedan član jedan glas“, u kojima nema imovinskih prava niti udjela u kapitalu, taj institut ne primjenjuje. Tako se odredba čl. 31. st. 2. ZS-a primjenjuje samo na klub-s.d.d., a ne na udruge. Na vjerodostojnost natjecanja ne utječe činjenica tko kontrolira neki klub, već činjenica da te iste osobe izravno ili neizravno utječu na druge klubove. Zbog toga treba jasno lučiti institute višestrukog i većinskog sudjelovanja.

\subsubsection{Prijedlozi de lege ferenda}

Diferentia specifica u zakonskoj definiciji udruge, ${ }^{48}$ koja je razlikuje od trgovačkih društava, jest određenje da cilj udruge ne može biti stjecanje dobiti niti drugih gospodarskih procjenjivih koristi. Udruga može, uz djelatnosti kojima ostvaruje svoje ciljeve utvrđene statutom, obavljati i neku pomoćnu djelatnost kojom stječe prihod, ali djelovanje udruge sveukupno mora biti neprofitno. Ako u obavljanju djelatnosti udruga ostvari dobit, ona se mora koristiti isključivo za obavljanje i unapređenje djelatnosti udruge, a ne smije se isplaćivati članovima niti trećim osobama. Zbog neprofitne prirode udruge članska prava u njoj mogu biti isključivo upravljačka: a) pravo glasa i pasivno biračko pravo, b) pravo pobijanja odluka tijela udruge, c) pravo na obaviještenost, d) pravo na korištenje opreme, uređaja i prostorija udruge i e) pravo na činidbe udruge..$^{49}$ Naime, udruge kao neprofitne organizacije, per se, nisu poželjne mete investiranja. A kako članovi trebaju upravljati udrugom temeljem demokratskog očitovanja, a ne s obzirom na veličinu uloga, teško je prispodobiti okolnost da neki ulagač ima interes ulagati u klub-udrugu. Profesionalni nogomet, inter alia, jest posao koji kao i druge gospodarske djelatnosti iziskuje financijsku opremljenost. Postoje mogućnosti unutarnjeg, vanjskog ili hibridnog financiranja. Unutarnje je financiranje iz same djelatnosti kluba ili ulozima članova. Ako opseg ulaganja nije razmjeran s upravljačkim i imovinskim pravima, a u udruzi nije, niti uopće postoje imovinska prava, preostaje financiranje iz djelatnosti ili financiranje zajmovima koji će za vjerovnike biti rizični. Bez osiguranog financiranja, u

\footnotetext{
48 Čl. 4. Zakona o udrugama, Narodne novine br. 74/14, 70/17, 98/19.

49 Tako Barbić, J., o. c. u bilj. 28., str. 760. i dalje.
} 
nogometu nema niti sportskih rezultata. Kako ulagači u klub očekuju i upravljanje njime i profit odnosno mogućnost povrata uloženog, pravni oblik s.d.d. neprijeporno je njima privlačniji. Udruge koje su se donedavno oslanjale na ,sponzorske ugovore" koji su u stvarnosti bile prikrivene državne potpore jer su sponzori bili javnopravna tijela ili trgovačka društva u kojima oni imaju značajne udjele, pod pritiskom prava državnih potpora gube takav izvor financiranja. Imajući u vidu da su u strukturi prihoda naših klubova, za razliku od europskih, iznosi s osnova tv-prava i reklama, prodaje ulaznica i rekvizita zanemarivi, i da se oni ponajvećma financiraju prihodima s osnova transfernih obeštećenja i raznim oblicima neizravnih potpora (kao i sredstvima koja se raspodijele u natjecanju), naše klubove treba „otvoriti“ ulagačima.

De lege ferenda treba promijeniti odredbe o ustroju profesionalnih sportskih klubova i pored s.d.d.-a dopustiti i pravni oblik društva s ograničenom odgovornošću i komanditnog društva. Naime, zbog mogućnosti fleksibilnijeg ustroja, ta dva društva mogu se lakše prilagođavati poslovnim i sportskim idejama različitih ulagača. Postojeće bi udruge mogle sa strateškim ulagačem kao komanditorom koji ulaže sredstva osnovati komanditno društvo u kojem zadržavaju položaj komplementara. Licencija za sudjelovanje u prvoligaškom natjecanju tada se s udruge prenosi na komanditno društvo. Ako se klub-udruga kvalificira za prvoligaško natjecanje, trebalo bi odrediti razdoblje od godinu dana unutar kojeg bi morao započeti proces preoblikovanja u trgovačko društvo. Naime, tijekom jedne prvoligaške sezone moguće je provjeriti sportske domete kluba, pa ukoliko ostane u prvoligaškom natjecanju, morao bi se zaodjenuti istim pravnim ruhom koje nose ostali sudionici natjecanja. Takva bi promjena zahtijevala i dopunu odredbi o preoblikovanju. Naime, predlaže se da se udruge i nadalje mogu preoblikovati samo u s.d.d. po postojećim pravilima o preoblikovanju. Ali ta pravila treba dopuniti odredbama kojima će se urediti preoblikovanje s.d.d.-a u s.d.o.o. ili s.k.d. Najniži iznos temeljnog kapitala u s.d.o.o.-u treba povećati i vezati ga za parametre iz financijskih izvješća u prethodne tri godine.

Zbog gore naznačenog problema s primjenom instituta višestrukih udjela trebalo bi izrijekom propisati da se navedeni institut na primjeren način primjenjuje na udruge za razdoblje dok se one ne preoblikuju u trgovačko društvo, ili zajedno s jedinicom lokalne uprave ili samouprave odnosno s privatnim ulagačem ne osnuju komanditno društvo. Treba potaći ulaganja u profesionalne klubove tako da se ublaži odredbu o postotku udjela u temeljnom kapitalu s.d.d.-a. Ne treba ničim ograničavati slobodno stjecanje dionica do dosezanja praga od $50 \%$ temeljnog kapitala društva. Tako ukoliko netko namjerava steći dionice na koje otpada najmanje $50 \%$ temeljnog kapitala, treba ga obvezati da od Povjerenstva zatraži dopuštenje za stjecanje dionica. ${ }^{50} \mathrm{Na}$ taj način se ne priječi sloboda većinskog sudjelovanja u temeljnom kapitalu društva, kao što je to slučaj u njemačkom pravu, već se ovlašćuje Povjerenstvo da nadzire načine financiranja profesionalnih klubova i zaprečuje (uskratom dopuštenja) bilo kojem ulagaču da potkopava integritet

${ }^{50} \mathrm{U}$ tome smislu predlaže se izmijeniti odredbu čl. 32. st. 1. ZS-a. 
kluba i nogometnog natjecanja. Vanjskim se ulagačima u profesionalni sport olakšava donošenje investicijske odluke, bez ugrožavanja njegove vjerodostojnosti i stabilnosti.

Institut višestrukih udjela treba i nadalje ostaviti na vrlo niskoj razini, jer tako ne treba strahovati da imatelj udjela ispod $1 \%$ prema ukupnom temeljnom kapitalu društva-kluba može utjecati na oblikovanje volje toga kluba. Zbog lošeg iskustva s vertikalnim utjecajima na više klubova u našem profesionalnom nogometu, taj, uz Poljsku, najmanji iznos ograničenja višestrukog sudjelovanja treba zadržati. Odredbe o izvješćivanju, kao i sankcije zbog neizvješćivanja ili povrede odredbi o stjecanju udjela u klubovima ne treba mijenjati. Dobro je da institut ograničenja višestrukih udjela koegzistira s relativnim ograničenjem većinskog sudjelovanja $u$ temeljnom kapitalu kluba-s.d.d. Međutim, Povjerenstvu bi trebalo proširiti ovlasti nadzora nad financijskim ulaganjima u profesionalne klubove kojima ulagač stječe većinski udio u temeljnom kapitalu ili pravu glasa jednog kluba. Također, predlaže se dodatno razraditi kriterije na temelju kojih Povjerenstvo može donijeti odluku o zabrani ulaganja. Načelno bi negativno rješenje trebao biti izuzetak, a dopuštenje ulaganja pravilo. Uz proširivanje njegovih ovlasti, Povjerenstvo bi trebalo ovlastiti da naknadno prati ispunjava li ulagač obveze iz investicijskog plana i da po potrebi primjereno sankcionira ulagača koji ne ispunjava obveze iz toga plana. Da financijski i gospodarski razlozi ne nadvladaju sportsku čestitost, navijačku privrženost i mjesnu ukorijenjenost kluba, trebalo bi unutar HNS-a odnosno Udruge profesionalnih klubova prve nogometne hrvatske lige, po uzoru na njemačko rješenje, oblikovati kolegij, članovi kojeg bi bili dokazani stručnjaci s područja nogometa, prava i ekonomije. A to stručno tijelo trebalo bi ovlastiti da nadzire ulaganja u klubove i pravovremeno sprečava negativne gospodarske i sportske utjecaje. Odmjereno i usklađeno djelovanje toga tijela i Povjerenstva mogli bi dugoročno štititi profesionalni nogomet od prodora špekulativnih ulagača koji bi jednodimenzionalnim usmjerenjem na povrat investicije odnosno maksimalizaciju profita, mogli zanemariti idealne sportske ciljeve i narušiti održivost kluba. Takvu je ideju moguće odvojiti od atributa utopije tek kada se razriješe postojeće nepravilnosti i uspostavi vladavina prava u prvoligaškom nogometnom natjecanju.

\subsection{Ograničenje višestrukih udjela u autonomnom pravu UEFA-e}

Europska nogometna konfederacija autonomno stvara pravila po kojima se odvijaju natjecanja pod njezinim patronatom. Sastavni dio pravila o natjecanju su od 1999. postale i posebne odredbe o integritetu natjecanja (eng. ,Integrity of Club Competitions: Independence of the Club"). ${ }^{51}$ Danas su na snazi pravilnici

51 UEFA je prava pravila o ograničenju višestrukih sudjelovanja donijela 18. svibnja 1998. u vidu odluke (eng. resolution) koja je stupila na snagu 1999. Od 2001. navedena su pravila uvrštena u pravilnike UEFA-e o natjecanjima u njezinu djelokrugu. 
za natjecanje u europskoj ligi i ligi prvaka u razdoblju 2018. - 2021. ${ }^{52}$ Oba pravilnika u čl. 5. sadrže odredbe kojima se uređuje integritet natjecanja. Strogo je zabranjeno klubovima koji sudjeluju u tim natjecanjima držati udjele jedan u drugome (eng. Cros-Ownership). Propisano je da klub koji se natječe na europskoj razini ne smije: a) držati niti raspolagati udjelima drugog kluba koji se natječe u istom natjecanju, b) biti član drugog kluba i c) imati bilo kakve ovlasti ili utjecaj u vođenju ili upravljanju drugog kluba. Uz navedenu horizontalnu zabranu, propisuje se i vertikalno ograničenje višestrukog sudjelovanja tako da nijedna osoba ne može imati kontrolu ili utjecaj u više od jednog kluba. Propisuju se četiri slučaja kada se smatra da netko ima kontrolu ili utjecaj u klubu - trgovačkom društvu kapitala: a) kada drži većinu dionica ili udjela s pravom glasa, ${ }^{53} \mathrm{~b}$ ) kada ima pravo imenovati ili opozvati imenovanje većine članova upravljačke strukture, c) kada imatelj udjela na temelju sporazuma drugim imateljima udjela kontrolira većinu u društvu i d) kada je na bilo koji način kadar ostvarivati odlučujući utjecaj na donošenje odluka u klubu. Premda su navedena pravila o ograničenju odlučnog utjecaja jedne osobe na više klubova sročena za trgovačka društva kapitala, treba ih na primjereni način primjenjivati i na druga trgovačka društva i udruge. Jer u europskim natjecanjima ne sudjeluju samo klubovi koji su pravno ustrojeni u obliku dioničkog društva, već klubovi svih oblika, uključujući i one koji su posebnost pojedinih pravnih poredaka, primjerice njemački klubovi ustrojeni kao komanditna društva na dionice. Navedeno ograničenje višestrukih udjela nije tako strogo kao što je to slučaj u hrvatskom pravu. Tako jedan ulagač koji ima ključan utjecaj na donošenje odluka u jednom klubu, bilo da ima većinski udio u kapitalu ili pravu glasa toga društva, ili je položaj kontrolnog člana društva stekao obveznopravnim poslovima ili na drugi način, može držati udjele u drugim društvima-klubovima sve do visine koja se u širem smislu može kvalificirati kao kontrolna. UEFA nakon uvođenja navedenih odredbi nema problema s njihovom primjenom, jer ih klubovi svih pravnih oblika poštuju znajući da će se njihova povreda oštro sankcionirati, moguće i izbacivanjem iz europskog natjecanja. Navedenim pravilima ograničava se onoga tko kontrolira jedan klub da to čini i u drugim klubovima koji se natječu u istom europskom natjecanju, neovisno o pravnom obliku dotičnih klubova.

Odredbe o ograničenju višestrukih sudjelovanja tek 1999. postaju sastavnim dijelom autonomnog prava UEFA-e. Prva je verzija navedenog instituta nastala kao reakcija na neugodnu situaciju koja se dogodila na natjecanju europskog kupa kupova. Dogodilo se da su četvrtfinale tog natjecanja 1998. izborila tri kluba, $A E K$ Atena, Slavia Prag $i$ Vicenca SpA u kojima je većinski udio izravno ili preko svojih društava kćeri držalo trgovačko društvo čije su dionice bile uvrštene na Londonsku

52 UEFA izdaje gotovo istovjetne pravilnike koji se primjenjuju u pojedinom natjecanju. Postoje pravilnici za natjecanje u ligi prvaka i europskoj ligi. Vidi Regulations of the UEFA Champions League i Europa League Regulations, 2018-21 Cycle. Dostupno na https://www.uefa.com/MultimediaFiles/ Download/Regulations/uefa.pdf (pregledano 20. travnja 2020.).

53 U engleskoj verziji odredbe čl. 5.01 lit. c) Pravila UEFA-e o natjecanju u ligi prvaka rabi se termin shareholder, ali iz njemačke verzije teksta vidljivo je da se ne radi samo o dioničarima već o članovima drugih društava. Više o tome vidi Punte, J. H., „,Die verbandsrechtliche Baschränkung von Mehrfachbeteiligungen on Fußballklubs durch die UEFA“, Zeitschrift für Sport und Recht, 3/17, str. 94. 
burzu (ENIC PLC). O zakonitosti instituta višestrukog sudjelovanja odlučivao je Arbitražni sud za sport (eng, Court of Arbitration for Sport, nadalje: CAS) povodom tužbe protiv UEFA-e koju su podnijela dva kluba (AEK Atena, Slavia Prag).${ }^{54} \mathrm{CAS}$ je najznačajniji arbitražni sud za rješavanje međunarodnih sporova u sportu, ${ }^{55} \mathrm{i}$ prema stajalištu švicarskog saveznog suda (njem. das Bundesgericht), ,istinski vrhovni sud svjetskog sporta“. ${ }^{56}$ Odlučujući povodom žalbe trgovačkog društva ENIC PLC, Europska je komisija u veljači 2000. donijela odluku o njezinu odbijanju jer cilj instituta ograničenja višestrukog sudjelovanja nije ograničavanje tržišnog natjecanja, već zaštita integriteta nogometnog natjecanja koje organizira UEFA. ${ }^{57}$

Za razliku od ograničenja višestrukih i isprepletenih udjela, ne propisuju se, niti postoje ograničenja većinskog sudjelovanja u kapitalu jednog kluba, kao što je to slučaj u njemačkom nogometu što ćemo razmotriti u nastavku rada.

\section{OGRANIČENJE VEĆINSKOG SUDJELOVANJA U NOGOMETNIM KLUBOVIMA}

\subsection{Općenito}

Profesionalni nogometni klubovi u europskim zemljama ustrojeni su, uz rijetke izuzetke, u pravnom obliku trgovačkih društava i njima se upravlja na način kako se propisuje nacionalnim pravom društava. Nečija upravljačka i imovinska prava u društvu odraz su njegova opsega sudjelovanja u temeljnom kapitalu društva. ${ }^{58}$ Kapital i upravljanje dvije su strane iste medalje, a promjene na jednoj strani utječu na drugu. Klubovi su privlačni investicijski ciljevi, pa ulagači pokušavaju steći udio koji ih ovlašćuje da ostvaruju prevladavajući utjecaj na oblikovanje poslovne, financijske i sportske politike kluba. Uobičajeno je u europskom nogometu da se ulagačima dopusti preuzeti „kontrolni udio“ odnosno ostvariti prevladavajući utjecaj u jednom klubu. Radi očuvanja integriteta nogometnog natjecanja, takvim se ulagačima ograničava opseg udjela koji mogu držati u drugim klubovima u istom

54 AEK Athen end Slavia Prag, 20. kolovoza 1999., CAS 98/200.

55 CAS je utemeljen 1984., a nalazi se pod administrativnim i financijskim upravljanjem Međunarodnog vijeća za sportsku arbitražu (eng. International Council of Arbitration for Sport - ICAS).

56 Više o tome vidi odluku švicarskog saveznog suda od 27. svibnja 2003., dostupno na http//www. swissfederaltribunal.com. (pregledano 11. travnja 2020.). Prema stajalištu Vrhovnog saveznog suda SR Njemačke u odluci Pechtein CAS je pravi arbitražni sud prema par. 1025. st. 1. i par. 1032. st. 1. Zivilprocessordnunga, a ne samo tijelo saveza ili neko drugo tijelo za rješavanje sporova. Više o tome vidi Bundesgerichof-BGH, KZR 6/15, 6. srpnja 2016., http//lexetius.com. (pregledano 12. travnja 2020.).

57 Tako EU-Kommission, COMP/37.806 (ENIC/UEFA), rbr. 35. Više o tome vidi Weiler, S., o. c. u bilj. 5., str. 95 .

58 Dionička su društva diljem Europe zadržala kategoriju temeljnog kapitala. Društva s ograničenom odgovornošću u pojedinim su državama zadržala kategoriju temeljnog kapitala, primjerice Njemačka, Austrija, Hrvatska, a u pojedinim državama je ona ukinuta, primjerice Francuska, Nizozemska i Velika Britanija u kojima se primjenjuje solventno orijentirani sustav zaštite vjerovnika. Više o tome vidi Höfer, C., „Flex-GmbH- eine solvenzorientierte Schwester-Rechtform für die GmbH?“, Zeitschrift für Gesellschaft-, Unternehmens- und Steuerrecht der GmbH und GmbH \& Co. KG, 8/16, str. 405. 
natjecanju. Propisivanjem ograničenja višestrukog sudjelovanja nije se spriječilo ulagača da ostvaruje prevladavajući utjecaj u jednom klubu. Takvo ograničenje ulaganja u vidu ograničenja odnosno zabrane većinskog sudjelovanja u jednom profesionalnom klubu već dva desetljeća postoji u njemačkom nogometu u vidu pravila ,50+1“. Od svih europskih zemalja, pored Njemačke, jedino se u Austriji i Švedskoj postavlja prag do kojeg jedan ulagač može imati udjele u nogometnom klubu, ${ }^{59}$ a kako su pravila bliska njemačkom modelu, u nastavku će se razmotriti samo njemačko rješenje. Kao što smo prethodno vidjeli, u našem se pravu ne propisuje zabrana većinskog sudjelovanja u temeljnom kapitalu jednog klubas.d.d., već se obvezuje stjecatelja dionica, koji namjerava prijeći prag od $25 \%$ udjela u temeljnom kapitalu s.d.d., da zatraži suglasnost Povjerenstva. Dionice može zakonito steći jedino ako prethodno dobije suglasnost za stjecanje, pa se može kazati da je u našem pravu načelno dopušteno stjecati većinske udjele u temeljnom kapitalu, a izuzetak je od toga pravila situacija kada Povjerenstvo uskrati zatraženu suglasnost. Dočim, u njemačkom se autonomnom pravu propisuje načelna zabrana stjecanja većinskog udjela u jednom klubu, uz mogući izuzetak o kojem odlučuje predsjedništvo nogometne lige (Deutsche Fußball Liga-DFL).

\subsection{Pravilo ,50+1“ kao diferentia specifica njemačkog profesionalnog nogometa}

Za razliku od većine europskih zemalja, u SR Njemačkoj se uz ograničenje višestrukih udjela u profesionalnim klubovima propisuje i zabrana većinskog sudjelovanja u jednom klubu. Jedan ulagač tako niti u jednom klubu koji se profesionalno natječe u prvoj i drugoj ligi (njem. Bundesliga, Zweiten Bundesliga), ne smije imati udio koji doseže polovinu temeljnog kapitala ${ }^{60}$ kluba ustrojenog $\mathrm{u}$ pravnom obliku društva kapitala. ${ }^{61}$ Nakon što zadovolje sportske, ekonomske i pravne preduvjete propisane autonomnim pravom nogometnog saveza (Deutsche Fußball Bund - DFB), profesionalni klubovi dobivaju licenciju, dopuštenje za sudjelovanje u natjecanju koje dodjeljuje Udruženje klubova (njem. Die Liga-

59 Više o tome vidi Punte, J. H., o. c. u bilj. 4, str. 110. i dalje.

60 Temeljni je kapital onaj dio vlastitog kapitala koji članovi unose osnivanjem društva ili poslije povećanjem temeljnog kapitala. On nije kapital u ekonomskom ili kreditnom smislu, već je to računovodstvena kategorija i ulazi u pasivu društva, a tim se kapitalom ne odgovara za obveze. Više o tome vidi Barbić, J., Pravo društava, Knjiga druga, Društva kapitala, Svezak I., Dioničko društvo, 5. izd., Zagreb, 2010., str. 45. i dalje Veil, u Scholz Kommentar zum GmbHG, 11. izd., Köln, 2014., § 5 rbr. 7.

61 Osnovna je značajka tih društava da se ne mogu osnovati bez unosa kapitala, a mogu se financirati vlastitim i vanjskim (tuđim) kapitalom. Kao protuteža činjenici da u društvima kapitala članovi načelno ne odgovaraju za obveze društva, na osnovi unosa najmanje vrijednosti koje odgovaraju iznosu temeljnog kapitala društvu se omogućuje da raspolaže s imovinom koja mu je nužna za ustroj poduzeća i istupanje na tržištu. Važnost temeljnog kapitala u službi zaštite vjerovnika očituje se kao: a) početna kapitalna opskrbljenost za početak gospodarskog djelovanja društva, b) zaštita od latentne insolventnosti društva i c) kao ozbiljnost i pripremljenost ulaska u poduzetnički pothvat. Osim te zaštitne uloge temeljni kapital je značajan i radi uređenja unutarnjih odnosa u društvu. Više o tome vidi Hennrichs, J. „Kapitalschutz bei GmbH, UG und SPE“, Neue Zeitschrift für Gesellschaftsrecht, 28/2009, str. 292. i dalje. 
Fußballverband e.V.). ${ }^{62}$ Osamdesetih i devedesetih godina, uslijed profesionalizacije nogometa, klubovi-udruge osnivali su trgovačka društva kapitala i na njih prenosili dopuštenje za sudjelovanje u natjecanju. Udruge su najčešće pronalazile jednog ili više strateških ulagača i na njih prenosile određeni dio udjela u nositelju licencije, u dioničkom društvu, komanditnom društvu na dionice ili u društvu s ograničenom odgovornošću. ${ }^{63} \mathrm{U}$ nakani da se izbjegne val preuzimanja profesionalnih klubova koji je tada zapljusnuo engleski, španjolski i talijanski nogomet, $D F B$ je 1998. donio pravila koja će stranim ulagačima pokazati da „Bunsliga nije pravo mjesto za tipično komercijalna ulaganja“. ${ }^{64}$ Klubovi se ni za kakvu cijenu ne smiju spustiti na razinu „milijarderovih igračaka“ i $D F B$ je dužan pravnim sredstvima zaštiti vjerodostojnost, integritet i stabilnost natjecanja. Statutom $D F B$-a i statutom Udruženja klubova utvrdio se strateški položaj udruge u oblikovanju volje kluba - trgovačkog društva kapitala neovisno o visini ulaganja vanjskog ulagača, tzv. pravilo , ,50+1“ “. ${ }^{65}$ Po tome pravilu udruga-majka (njem. Mutterverein) mora zadržati većinski udio u temeljnom kapitalu i u pravu glasa kluba-d.d. ili d.o.o. Ukoliko je društvo kćer ustrojeno kao komanditno društvo na dionice (njem. KGaA), udruga - društvo majka (njem. Mutterverein) ili njezino društvo kćer u kojem udruga drži $100 \%$ udjela, onda mora biti u položaju komplementara. Vanjski ulagači mogu biti komanditori ili imatelji udjela ispod praga od $50 \%$. Pravilo ,50+1“ sadrži iznimku prema kojoj se vanjskom ulagaču može dopustiti da stekne većinski udio u klubu pod uvjetom da je više od dvadeset godina neprekidno i značajno potpomagao (njem. ununterbrochen und erheblich gefördert) klub. ${ }^{66} \mathrm{O}$ izuzetku odlučuje predsjedništvo nogometne lige (Deutsche Fußball Liga-DFL). Ono je ovlašteno sadržajno odrediti pravni standard „značajna potpora“, a istovremeno zapriječiti

62 DFB je 2001. ovlaštenje za dodjelu licence prenio na udruženje klubova (Die Liga-Fußballverband e.V.), a društvo kćer toga društva Njemačka nogometna liga (Deutsche Fußball Liga-DFL) ovlašteno je organizirati natjecanje. Više o tome vidi Schaefer, P., „Die Vereinbarkeit der “ $50+1 ”-$ Regel mit dem Europarecht“, Schriften Zum Sportrecht, Nomos, 2012., str. 136.

63 Njemački profesionalni klubovi ustrojeni su u pravnom obliku dioničkog društva, društva s ograničenom odgovornošću, ali i komanditnog društva na dionice koje je posebnost njemačkog prava (njem. $A G, G m b H, K G a A)$. Više o tome vidi Summerer, T., „Investoren für Bundesliga?“, Zeitschrift für Sport und Recht, 6/2008, str. 234.

64 Obrambeni stav jasno se iščitava iz izjave predsjednika DFB-a: „Ne želimo da naše tradicionalne klubove preuzimaju indijski ili arapski ulagači, makar dozvolili treneru neograničena sredstva u angažiranju igrača za prvu momčad." Više o tme vidi Punte, J. H., o. c. u bilj. 4, 2014., str. 4.

65 Najveća strukturna reforma njemačkog profesionalnog nogometa izvršena je 1998. kada se omogućilo prenošenje licence s kluba-udruge na trgovačka društva u kojima je udruga zadržala određene udjele. Izmjenama i dopunama statuta nogometnog saveza (Deutsche Fußball Bund (DFB)- Satzung od 24. listopada 1998.) uneseno je tzv. Pravilo ,50+1“. uređeno je odredbama $\S 16 \mathrm{c}$ Statuta DFB-a Pravilo, a istovjetne odredbe sadrži i § 8 Statuta udruge saveza profesionalnih klubova (Die Liga- FußBallverband e.V.) na koju su 2001. prenesene ovlasti organizacije profesionalnog nogometnog natjecanja 1. i 2. nogometne lige i dodjele licencije (dozvole za natjecanje). (Deutsche Fußball Bund-Satzung i Die LigaFußballverband e.V-Satzung dostupni na https://www.dfb.de/Fileadmin-Satzung.pdf, posjećeno ožujka 2020.).

66 Nakon trinaest godina primjene, 2011. Stalno arbitražno sudište za udruge i trgovačka društva profesionalne lige (njem. Ständigen Schidsgericht für Vereine und Kapitalgesellschaften der Lizenzligen) poništava navedenu iznimku. Odmah nakon toga, sročila se nova odredba o iznimci u literaturi nazvana po predlagaču predsjedniku kluba Hannover 96 Martinu Kindu Lex Kind koja je i danas na snazi. Više o tme vidi Punte, J. H., o. c. u bilj. 4, str. 106. 
ulagačima da okolišnim preuzimanjem društava koja su pomagala klubove, zaobiđu zabranu stjecanja većinskog udjela u klubu. ${ }^{67}$

Motivi za zabranu većinskog sudjelovanja vanjskih ulagača jesu: a) zaštita kluba - nositelja licence za natjecanje od nogometu stranih utjecaja i osiguranje gospodarske stabilnosti i konkurentnosti klubova, b) poticanje i očuvanje javnog ugleda i percepcije nogometnog saveza i klubova, c) održanje mehanizma solidarnosti kao osnove pouzdanosti i vjerodostojnosti natjecanja, d) zaštita klubova od stranih Hedge-fondova koji zbog prvenstva profita mogu nametati nogometu strane interese i e) da povlačenje ulagača iz kluba ili stečaj ulagača ne „povuče“ i klub u stečaj. ${ }^{68}$ Cilj je očuvanje vjerodostojnosti nogometa tako da on $\mathrm{u}$ vremenu vrtoglavih financijskih ulaganja ostane sportska igra, a ne preraste $\mathrm{u}$ natjecanje između bogatih pojedinaca, trgovačkih društva ili koncerna. DFB je ocijenio da bi većinsko sudjelovanje vanjskih ulagača moglo narušavati integritet $i$ stabilnost nogometnog natjecanja, jer bi se sportski interesi i dugoročna održivost mogli podrediti financijskim interesima ulagača. Primjerice transferiranjem najboljih igrača, sklapanjem sponzorskih ugovora ili ugovora o pravima s osnova televizijskog prijenosa utakmica i sl. mogu se uprihoditi sredstva koja se umjesto daljnjeg sportskog razvoja kluba mogu usmjeravati prema povratu ulaganja ili ekstra zaradi. Ako ne bi postojala zabrana prelaska kontrolnog postotka, brzo bi se stvorio veći rascjep između bogatih i siromašnih klubova, pa bi se umanjila neizvjesnost i privlačnost nogometnog natjecanja ${ }^{69}$ Naime, potiče se klubove da financijski ojačavaju postupno putem sportskog uspjeha koji privlači publiku, sponzore, povećava budžet kluba i sl. Sportski uspjeh s prikladnom financijskom strategijom osigurava klubu dugoročnu stabilnost i rast, a ulagačka strategija ne mora težiti za usklađivanjem sporta i kapitala, već može biti spekulativna. A rizična ulaganja ili ulagačevi poslovni problemi u stečajni ponor mogu povući i klub. Kad udruga kao društvo-majka ima prevladavajući utjecaj u društvu kapitala, veća je vjerojatnost da će se spriječiti tržišni rizici imanentni klasičnoj tržišnoj utakmici. Nogometni klubovi su ukorijenjeni u nekoj sredini i neprofitna, socijalna i lokalno-politička narav udruge pruža jače uporište za razborito upravljanje i održavanje autarkičnosti kluba i postoji manja žudnja za profitom nego li je to kod vanjskih ulagača.

Navedeno je pravilo kritizirano kao smetnja koja blokira klubove da pristupe novim izvorima kapitala kojima raspolažu konkurentni klubovi iz drugih zemalja. ${ }^{70}$ Ulagači će zaobilaziti njemačke klubove koji se neće moći financijski ni sportski nositi s konkurencijom. Sumnja da će njemački nogomet izgubiti dotadašnju vrsnoću pokazala se neutemeljenom, jer se njemačka reprezentacija i klubovi kontinuirano zadržavaju u elitnom razredu europskog i svjetskog nogometa.

67 Ibidem, str. 108.

68 Više o tome vidi Summerer, T., o. c. u bilj. 63, str. 236.

69 Tako Schaefer, P., o. c. u bilj. 62, 2012., str. 140.

70 Deutcher, J., ,50+1-Regelung in der Fußball-Bundesliga- Zur Mehrheitsbeteiligung von Investoren an Fußballklubs“, Zeitschrift für Sport und Recht, 3/2009, str. 98. 
Uz zabranu većinskih udjela, u njemačkom pravu se od 2015. propisuje i ograničenje višestrukih udjela. ${ }^{71} \mathrm{Na}$ temelju odredbe $\S 8$ st. 6 . Statuta njemačke nogometne lige $(D F L)$ propisuje se da nitko tko izravno ili neizravno drži iznad 10 $\%$ udjela u pravu glasa ili (temeljnom) kapitalu jednog društva-kluba ne smije imati udjele u drugim klubovima-društvima koji sudjeluju u istom natjecanju. Imatelj koji prijeđe navedeni prag može jedino u tome klubu stjecati daljnje udjele u pravu glasa ili kapitalu, ali samo do opsega koji ne smije doseći većinu udjela u tome društvu. Vertikalno držanje udjela ograničava se, kako u opsegu udjela, tako i u broju klubova u kojima netko može držati udjele. Adresati odredbi o ograničenju višestrukih udjela jesu ulagači koji već drže udio u kapitalu ili pravu glasa jednog društva i to u iznosu manjem od $10 \%$. Jedino oni mogu stjecati udjele u drugom klubu ili druga dva kluba. Drugačije kazano, ograničenje višestrukih udjela na tri kluba tiče se ulagača koji drže ispod $10 \%$ udjela u pravu glasa ili kapitalu društva. A oni koji drže udjele u jednom klubu iznad toga postotka, tj. od 10 do $50 \%$, ne smiju stjecati udjele u drugim klubovima iste razine natjecanja. Uvođenje instituta ograničenja višestrukih udjela nije utjecalo na institut zabrane većinskih udjela. Uzajamno se nadopunjujući, oni štite integritet nogometnog saveza i klubova, osiguravaju vjerodostojnost i neizvjesnost natjecanja i potiču povjerenje gledatelja i javnosti. A ulagači prema kojima su postavljene navedene zapreke, upravo zbog njihovog postojanja i fer odnosa u sportskom i gospodarskom smislu, bivaju snažno motivirani da investiraju u njemačke nogometne klubove.

Neumitno je da oba instituta, u svim pravnim porecima, negativno utječu na slobodu ulaganja i sudjelovanja na nogometnom tržištu, odnosno njima se ograničava, sprečava i narušava tržišno natjecanje. U nastavku će se razmotriti postoje li razlozi postizanja legitimne svrhe i razmjernosti kojima se može opravdati postojanje navedenih instituta unatoč očitoj činjenici da se njima povređuju odredbe europskog prava tržišnog natjecanja.

\section{USKLAĐENOST OGRANIČENJA VIŠESTRKOG I VEĆINSKOG SUDJELOVANJA S EUROPSKIM PRAVOM TRŽIŠNOG NATJECANJA}

\subsection{Primjena europskog prava tržišnog natjecanja na sport}

Autonomija nogometnih saveza ne znači bezgraničnu slobodu uređenja svih unutarnjih odnosa i rješavanja svih spornih pitanja. Naime, autonomiju savez ne daje samom sebi već je ona izvedena iz državnog prava višeg reda (njem. höherrangiges staatliches Recht). ${ }^{72}$ Europsko pravo kao ,pravo višeg reda“ značajan

71 Zanimljivo je da je do 26. ožujka 2015. SR Njemačka bila jedina europska država u kojoj se nije, niti na zakonodavnoj niti na autonomnoj razini, propisivalo ograničenje višestrukih udjela. Tako Punte, J. H., „Die verbandsrechtliche Baschränkung von Mehrfachbeteiligungen on Fußballklubs durch die UEFA“, Zeitschrift für Sport und Recht, 3/17, str. 94.

72 Više o tome vidi ibidem, str. 108. 
je korektiv autonomije nogometa, a posebno imajući u vidu europska natjecanja u kojima se natječu klubovi - trgovačka društva. Sport se kao područje djelovanja Europske unije u primarnom europskom pravu prvi put uređuje odredbom čl. 165. Ugovora o funkcioniranju Europske unije iz Lisabona 2008. (nadalje: EFEU). ${ }^{73}$ Unija će doprinositi promociji europskog sporta, vodeći računa o posebnoj prirodi sporta, njegovim strukturama koje se temelje na dragovoljnoj aktivnosti te na njegovoj socijalnoj i obrazovnoj funkciji. Prepoznavanje „posebnosti sporta“ kao rukovodnog načela u primjeni europskog prava na sport značajan je doprinos zaštiti sportske autonomije. Međutim, otvorenim ostaje pitanje primjenjuje li se navedena odredba i na profesionalni sport. Njezinim gramatičkim tumačenjem, prima facie, mogla bi se braniti teza da je, zbog dragovoljnosti uključenja, socijalne i pedagoške zadaće sporta, riječ samo o amaterskom sportu, međutim, koristeći metode sistemskog i teleološkog tumačenja, preteže teza da se navedena odredba proteže i na profesionalni sport čiju posebnost treba priznavati. Godinu ranije, 2007., Europska komisija kao „europska vlast za tržišno natjecanje“ ${ }^{74}$ nakon niza prethodnih aktivnosti u sportskom području, donosi prvi sveobuhvatni dokument za sport u vidu tzv. Bijele knjige sporta (eng. White Paper on Sport) ${ }^{75} \mathrm{U}$ objašnjenjima uz dokument se ističe da se na sport primjenjuje pravo tržišnog natjecanja i odredbe o unutarnjem tržištu sve dok sport predstavlja gospodarsku aktivnost. Sud Europske unije ustaljeno već desetljećima donosi odluke o podvrgavanju sporta, posebno profesionalnog nogometa, pod prisilne odredbe europskog prava. Sredinom sedamdesetih godina prošlog stoljeća, u predmetu Walrave and Koch ${ }^{76}$ utvrđuje se da je sport predmet uređenja europskog prava ukoliko predstavlja gospodarsku aktivnost, a navedeni se stav primjenjivao svim sportskim odlukama naredna tri desetljeća. ${ }^{77}$ Obrat se dogodio 2006. u predmetu Meca-Medina ${ }^{78}$ u kojem se prvi put odlučivalo o primjeni europskog prava tržišnog natjecanja na sport. ${ }^{79}$ Sud je ustvrdio da pravila koja sportski savezi donose i kvalificiraju kao „čisto sportska“ ne treba olako isključivati iz dosega odredbi prava tržišnog natjecanja, jer se njima može narušavati tržišno natjecanje, odnosno može doći do zlouporabe vladajućeg položaja na tržištu. ${ }^{80}$ Povezanost sportskog i gospodarskog djelovanja tako je

73 Ugovor iz Lisabona o izmjeni Ugovora o Europskoj uniji i Ugovora o osnivanju Europske zajednice (SL C 306, 17. XII. 2007.).

74 Tako Punte, J. H., o. c. u bilj. 4, 2014., str. 82.

75 Više o tome vidi https://ec.europa.eu/sport/dokuments/white-paper-full_en.pdf.

76 Prva odluka Suda Europske unije o primjenjivosti europskog prava na sport donesena je u predmetu Walrave and Koch, 12. prosinca 1974., C-36/74.

77 Vidi predmete: Doná, 14. srpnja 1976., C -13/76, Bosman, 12. prosinca 1995., C-415/93, Lehtonen, 13. travnja 2000., C-176/96, Deliége, 11. travnja 2000., C-51/96 i C-191/97, Kolpak, 18. svibnja 2003., C438/00 i Simutenkov, 12. travnja 2005., C-265/03.

78 Meca-Medina, 18. lipnja, 2006 C-519/04. Odluka se ne tiče nogometa već profesionalnog plivanja. Dva su plivača na duge staze osporavala usklađenost pravila o antidopingu Međunarodnog olimpijskog odbora i Međunarodnog saveza za vodene sportove s odredbama europskog prava tržišnog natjecanja.

79 Nezavisni odvjetnik Lenz je u 1995. u predmetu Bosman razmatrao utjecaj sportskih pravila na povredu europskog prava tržišnog natjecanja, ali je prva sudska odluka koja se odnosila na primjenu europskog prava tržišnog natjecanja na sport donesena u predmetu Meca-Medina. Više o tome vidi Punte, J. H., o. c. u bilj. 4, 2014., str. 87.

80 Ibidem. 
isprepletena da se bez konkretne detaljne raščlambe ne može a priori odlučiti radi li se samo o čisto sportskom pravilu tzv. lex ludica ili pravilu kojemu su imanentni gospodarski i financijski učinci. Sud se pritom pozvao na kriterije za ocjenu sukladnosti pravila nekog udruženja s europskim pravom tržišnog natjecanja koji su utvrđeni četiri godine ranije, 2002. u predmetu Wouters. ${ }^{81}$ Usklađenost pravila treba razmotriti posebno uzimajući u obzir: a) sveukupni kontekst u kojem se pravila primjenjuju, njihove učinke i nakanjene ciljeve, b) jesu li ograničavajući učinci svrhoviti i c) jesu li učinci razmjerni svrsi. Kriteriji „legitimnog cilja“, „nužnosti“ i „razmjernosti“, potvrđeni su i u odlukama Europskog suda kojima se propitivala usklađenost pravila sportskog saveza s odredbama europskog prava o zlouporabi vladajućeg položaja ${ }^{82}$ kao i prilikom ukidanja diferencijacije između gospodarskih i negospodarskih pravila sportskog saveza. ${ }^{83}$ Iz navedenih je odluka vidljivo da će Sud primjenjivati odredbe prava tržišnog natjecanja na sport bez obzira na njegovu posebnost. ${ }^{84} \mathrm{Je}$ li neko sportsko pravilo podložno kontroli Suda, odnosno je li usklađeno s odredbama europskog prava tržišnog natjecanja, ne ovisi o stajalištu ili procijeni sportskih saveza ili institucija, već se ono treba podvrći testu kriterija koji su utvrđeni u odredbama čl. 101. i 102. UFEU-a. ${ }^{85}$ Sud prepoznaje i priznaje „posebnost sporta“, što je vidljivo iz svih dosadašnjih „,sportskih odluka“, međutim, to priznanje ne znači da se sportu mora osigurati tako široka autonomija koja priječi doseg primjene europskog prava na sport. ${ }^{86}$

\subsection{Usklađenost ograničenja višestrukog i većinskog sudjelovanja $s$ europskim pravom tržišnog natjecanja}

Na temelju monopolno-hijerarhijskog ustroja, nogometni su savezi ovlašteni uređivati vlastite poslove i neovisno o javnoj vlasti donositi pravila, primjenjivati ih i nadzirati njihovu primjenu. Zbog činjenice da je sudjelovanje u profesionalnom nogometu gospodarska djelatnost, autonomija tih saveza je ograničena, jer je kao i svaka druga gospodarska djelatnost, i nogometna djelatnost podložna kontroli javnog poretka. Europski Sud i Europska komisija ustaljeno potvrđuju da je sport, amaterski i profesionalni, predmet uređenja europskog prava. Jesu li instituti ograničenja višestrukog i zabrane većinskog sudjelovanja usklađeni s europskim pravom tržišnog natjecanja, ovisi o njihovoj raščlambi u svjetlu kriterija sadržanih

${ }^{81}$ Meca-Medina, rbr. 42. U predmetu Wouters, 22. ožujka 2002., C-309/99 propitivala se usklađenost ograničavajućih pravila nizozemske odvjetničke komore s europskim pravom tržišnog natjecanja.

82 Tako u predmetu MOTOE, 1. srpnja 2008., C-49/07.

83 Tako u predmetu Olimpique Lyonnais, 16. ožujka 2010., C-325/08.

84 Sud Europske unije nije vezan svojim ranijim odlukama, no u svojim presudama nastoji osigurati visoku razinu ujednačenosti i konzistentnosti. To je izrazito vidljivo u praksi kojom se u obrazloženju pojedinih odluka poziva na sadržaj ranijih presuda. Načela tumačenja prava tržišnog natjecanja razvijena u prijašnjim odlukama Sud konzistentno primjenjuje u novim presudama.

85 Tako Punte, J. H., o. c. u bilj. 4., str. 91.

86 Više o tome vidi Sander, G., Sasadi, A, Sport im Spannungsfeld von Recht, Wirtschaft und europäischen Grundfreiheiten, Berlin, 2009., str. 109. i dalje. 
u odredbama čl. 101. i 102. UFEU-a. Europski sud nije odlučivao o navedenom pitanju. Ali se o zaštiti etičkih i ekonomskih vrijednosti profesionalnog nogometa intenzivno raspravlja već dvadeset godina nakon što je CAS odlučio da su pravila nacionalnih nogometnih saveza i UEFA-e, kojima se ograničava mogućnost ulaganja u više profesionalnih nogometnih klubova, ograničavajuća u smislu europskog prava tržišnog natjecanja, ali se njima postiže legitiman cilj očuvanja sportskog integriteta, te su prikladna i nužna, a isto je stajalište zauzela i Europska komisija. ${ }^{87}$

Na temelju čl. 101. st. 1. zabranjeni su sporazumi među poduzetnicima, odluke udruženja poduzetnika i usklađeno djelovanje koji bi mogli utjecati na trgovinu među državama članicama i koji imaju za cilj ili posljedicu sprečavanje, ograničavanje ili narušavanje tržišnog natjecanja. „Poduzetnikom“ se, na temelju ustaljene prakse Europskog suda, smatra svaki „subjekt koji se bavi gospodarskom djelatnošću bez obzira na njegov pravni status i način financiranja ${ }^{88}$ Sud određuje da je djelatnost ,gospodarska“ uvijek kada se dobra ili usluge nude na određenom tržištu. ${ }^{89}$ Takvim širokim objektivnim određenjem ne zahtijeva se namjera stjecanja dobiti. Profesionalni nogometni klub, neovisno o svome ustrojbenom obliku, svakako jest poduzetnik i adresat navedene odredbe primarnog europskog prava. Europski je sud utvrdio da su različita sportska udruženja, pa tako i nacionalni i međunarodni nogometni savezi, udruženja profesionalnih klubova i sl. gospodarski aktivni pa ispunjavaju sve zahtjeve iz odredbi čl. 101. st. 1. UFEU-a. ${ }^{90}$ Ako su institute ograničenja višestrukih odnosno većinskih udjela oktroirali nacionalni ili međunarodni nogometni savezi, treba ih pravno kvalificirati kao odluke udruženja poduzetnika kojima se smjera ili utječe na sprečavanje, ograničavanje ili narušavanje tržišnog natjecanja. Ti su instituti protivni prisilnim odredbama europskog prava tržišnog natjecanja, jer ograničavaju mogućnosti ulaganja u nogomet i sprečavaju zainteresirane da alociraju svoja sredstva u više klubova u opsegu koji žele, odnosno koji tržište dopusti. ${ }^{91} \mathrm{U}$ svim dosadašnjim ,,sportskim odlukama“ Europski sud se osvrnuo na posebnost sporta i raščlanjivao mogućnosti opravdanja autonomnog

87 AEK Athen end Slavia Prag, 20. kolovoza 1999., CAS 98/200. EU-Kommission, COMP/37.806 (ENIC/UEFA), rbr. 35. Više o tome vidi ibidem, str. 95.

88 Vidi predmete: Höfner, 15. siječnja 1991, C-41/90, Albamy, 21. srpnja 1999., C-67/96.

89 Tako u predmetu Aéroports de Paris, 24. listopada 2002., C-82/01.

90 Tako u predmetima Meca-Medina, 18. lipnja, 2006 C-519/04. i MOTOE, 1. srpnja 2008., C-49/07.

91 Tako Schaefer, P., o. c. u bilj 62, str. 142. 
propisivanja u sportu. Pri tome neizostavno poziva na temeljna načela europskog prava, a posebice na načelo legitimnog cilja i razmjernosti. ${ }^{22}$

Cilj neke mjere je legitiman kada nije nedopušten, zasniva se na razboritim temeljima i kada je provediv. ${ }^{93}$ Oba instituta služe zaštiti nogometnog natjecanja, ali i ,nogometnog proizvoda“ u cijelosti. Njima se osigurava sportski primat nad čisto komercijalnim interesima tržišno orijentiranih ulagača. Ograničenjem vertikalnog utjecaja jedne osobe na više klubova štiti se osnovna sportska vrednota čestitosti natjecanja. To se čini i odredbama o ograničenju ili nadzoru nad stjecanjem značajnog udjela u kapitalu ili pravu glasa jednog kluba. Primjerice, u našem je pravu propisani prag od $25 \%$ udjela u temeljnom kapitalu kluba s.d.d., prijelazom kojeg se mora zatražiti suglasnost Povjerenstva za dodatno stjecanje dionica, ili zabrana većinskih udjela u vidu pravila ,50+1“, svojstvena njemačkom profesionalnom nogometu, čime se omogućava da udruga-društvo majka stalno zadržava prevladavajući utjecaj u klubu-društvu kćeri i na temelju demokratski oblikovane volje (jedan član jedan glas) u udruzi potiče sportske interese i priječi financijske ulagače da sve snage budu usmjerene na dosezanje i maksimalizaciju dobiti. Tako se najbolje zaštićuju društveni interesi i vrijednosti nogometa od pritiska profitno orijentiranih interesa različitih ulagača. Stabilnost i integritet nogometnih natjecanja kao uopće vjerodostojnost nogometnog saveza kao organizatora natjecanja, bili bi ozbiljno narušeni kad ne bi postojala ograničenja ulaganja. Kontroliranje više klubova u istom natjecanju ne samo da dokida osnove sportskog morala, već odvraća gledatelje, sponzore, ulagače i kontaminira cijeli sustav nogometnog sporta.

Nakon što se utvrdilo da je svrha navedenih instituta legitimna, treba se osvrnuti na razmjernost mjera i propitati jesu li navedena ograničenja prikladne i nužne mjere, odnosno je li način dosezanja legitimnog cilja previše tegoban za adresate. Profesionalni nogomet istovremeno prožimaju sportske vrijednosti i gospodarski interesi. Tradicionalne vrijednosti solidarnosti, čestitosti i jednakosti prilika podgrijavaju navijačku privrženost, a profesionalni klub bez navijača postaje puko trgovačko društvo s profanim materijalističkim ciljem stjecanja

92 Načelo razmjernosti izrijekom se ne propisuje niti u javnom niti u privatnom pravu već se izvodi iz ustavnopravnog načela vladavine prava. Kako primjena toga načela nije ograničena na određenu granu prava, ona je sveprisutna. Više o tome vidi Weiler, S., o. c. u bilj 5, str. 244. Pojam razmjernosti u sustavu prava Europske unije susreće se u dvojakom značenju. Tako se pojam razmjernosti može susresti kao regulatorno pravilo koje određuje dopustivost donošenja sekundarnog zakonodavstva institucija EU-a u odnosu na nadležnosti država članica, ali i kao opće načelo koje služi zaštiti subjektivnih prava i objektivnom poretku u cjelini. Brojna su načela koja je Sud Europske unije ustanovio kroz svoju dugogodišnju praksu. U opća načela prava ubrajaju se: načelo poštovanja temeljnih procesnih jamstava, učinkovite pravne zaštite, razmjernosti, pravne sigurnosti, legitimnih očekivanja, zabrane retroaktivnosti, jednakog postupanja i zabrane diskriminacije itd. Primarna svrha načela razmjernosti ogleda su u funkciji ograničenja djelovanja javne vlasti, a razmjernost mjere javne vlasti privatnom interesu u koji se takvom mjerom zadire, utvrđuje se kroz tri faze. Prije svega potrebno je utvrditi je li poduzeta mjera primjerena cilju koji se želi postići; je li nužna za postizanje tog cilja ili ga je moguće postići nekom manje restriktivnom mjerom te nameće li mjera obvezniku pretjerani teret u odnosu na cilj koji se njom nastoji postići. Radi se o testovima primjenjivosti, nužnosti i razmjernosti stricto sensu. Više o tome Vezmar Barlek, I., „Primjena načela razmjernosti u praksi Suda Europske unije“, Zbornik Pravnog fakulteta Sveučilišta u Rijeci, v. 38, br. 1, str. 674.

93 Tako Schaefer, P., o. c. u bilj. 62, str. 188. 
dobiti. Da gospodarski interesi ne bi zatomili tradicionalne sportske interese bilo je nužno ograničiti mogućnost jednom ulagaču da kontrolira više klubova. Prirodni ekonomski impuls za stvaranjem monopola ili oligopola, moguće je osujetiti samo ograničavanjem mogućnosti utjecaja na više klubova. ${ }^{94}$ Navedene mjere nužne su radi osiguranja integriteta natjecanja. Njima se ne štiti samo sportski interes sudionika natjecanja već se istovremeno štite i njihovi gospodarski interesi. Dopustivši nekome da utječe na sportski tijek natjecanja, onemogućili bi se ostali klubovi da ostvare bolji sportski rezultat koji je preduvjet privlačenja navijača, sponzora, ulagača i sl. Zbog toga treba zaključiti da se razmatranim institutima postiže legitiman cilj i to na prikladan način, te da je njihovo postojanje nužni uvjet očuvanja i razvoja profesionalnog nogometa.

Izloženi razlozi koji opravdavaju postojanje navedenih zabrana i ograničenja u profesionalnom nogometu mogu se istaći i prilikom razmatranja usklađenosti odredbi europskog prava o slobodnom protoku kapitala, ali takvo razmatranje prelazi opseg rada.

\section{ZAKLJUČAK}

Za razliku od drugih gospodarskih djelatnosti, u profesionalnom se nogometu postavljaju ograničenja na temelju kojih se onemogućava jednom ulagaču da kontrolira više klubova. Institut ograničenja višestrukih udjela uređuje se legislativnim instrumentima kojima se uređuju odnosi u sportu, primjerice u Hrvatskoj, Poljskoj, Španjolskoj, ili, što je učestalije, autonomno se uređuju odredbama pravila o nogometnom natjecanju, primjerice, u Njemačkoj, Italiji, Francuskoj, Engleskoj i dr. U europskim državama uočavaju se dva osnovna nomotehnička pristupa uređenju toga instituta. Po prvome se određuje prag u vidu postotka sudjelovanja u temeljnom kapitalu kluba-društva, koji osoba koja već ostvaruje prevladavajući utjecaj u jednom klubu, ne može prijeći. Najniži je prag u iznosu od $1 \%$ propisan za naše i poljske profesionalne klubove, 5 \% za španjolske, a $10 \%$ za engleske. U SR Njemačkoj određuje se da nitko tko izravno ili neizravno drži iznad $10 \%$ udjela u pravu glasa ili kapitalu jednog društva-kluba ne smije imati udjele u drugim klubovima-društvima koji sudjeluju u istom natjecanju, ali tko drži udjele ispod toga praga može stjecati udjele samo u još dva kluba i to do visine toga praga. Drugi je način uređenja navedenog instituta bez propisivanja točnog praga ili postotka koji osoba koja kontrolira jedan klub ne smije prijeći. Po uzoru na autonomno pravo UEFA-e, talijanski, francuski i dr. nogometni savezi, onome tko kontrolira jedan klub, zaprečuju stjecanje udjela u drugim klubovima u vidu mogućnosti ostvarenja prevladavajućeg utjecaja, odnosno ostvarivanja odlučujućeg utjecaja na donošenje odluka u drugom klubu. Taj je sustav liberalniji (eng. investment friendly) jer omogućava ulagačima, koji kontroliraju jedan klub, da stječu udjele u drugim klubovima iznad $10 \%$, ali ispod onog postotka, koji bi mu

94 Više o tome vidi Weiler, o. c. u bilj. 5, str. 252. 
prema nacionalnom pravu društava omogućio prevladavajući odnosno odlučujući utjecaj u drugim klubovima. Adresati su navedenih odredbi svi profesionalni klubovi koji sudjeluju u istom natjecanju bez obzira na svoj pravni oblik.

U našem je pravu navedeni institut kao i apsolutna zabrana isprepletenih udjela ukotvljen u odredbe čl. 31. do 36. ZS-a u dijelu u kojem se uređuju odnosi u s.d.d.-u. A kako odredbe kojima se uređuju sportske udruge ne sadrže navedene institute, već ih samo periferno dotiču, i nedostaje odredba o upućivanju na njih, postoji pravna praznina. Radi očuvanja vjerodostojnosti i integriteta nogometnog i općenito sportskih natjecanja, tu prazninu treba popunjavati pozivajući se na relevantna pravna načela i doseg navedenih odredbi protegnuti i na udruge. To je condicio sine qua non uspostavljanja vjerodostojnosti nogometnog prvoligaškog natjecanja. Napokon se treba sankcionirati neprimjerena povezanost između zagrebačkih klubova-udruga. ${ }^{95}$ Kao organizator natjecanja, HNS je dužan spriječiti narušavanje integriteta natjecanja, a u konačnici Središnji državni ured za šport treba reagirati i primjereno sankcionirati opetovanu povredu odredbi o višestrukom odnosno isprepletenom sudjelovanju.

U našem pravu postoji načelna sloboda većinskog sudjelovanja u temeljnom kapitalu jednog kluba. Ali ulagač koji prijeđe propisani prag od $25 \%$ udjela u temeljnom kapitalu jednog kluba mora od Povjerenstva za profesionalne sportske klubove zatražiti dopusnicu za stjecanje dionica. Kako Povjerenstvo može obrazloženom odlukom osporiti stjecanje dionica iznad propisanog praga, ta je sloboda relativna. Međutim, sankcija za protupravno stjecanje dionica nije gubitak prava iz njih, već se ovlaštenje za ostvarivanje upravljačkih i imovinskih prava iz dionica prenosi na povjerenika i ono traje sve do trenutka dok se dionice ne otuđe. Radi privlačenja ulagača u profesionalne klubove predlaže se de lege ferenda povisiti navedeni prag na iznos od $50 \%$ dionica. Naime, u pravnim porecima u kojima postoji institut ograničenja višestrukog sudjelovanja u pravilu je slobodno stjecati udjele u jednom klubu i u njemu ostvarivati potpunu kontrolu. Na vjerodostojnost natjecanja načelno ne bi trebala utjecati okolnost kontrolira li jedan klub jedna ili više osoba i u kojem opsegu, već na to rerum natura utječe samo horizontalni i vertikalni utjecaj na više klubova. Međutim, izuzetak od navedenog pravila da se ne ograničava stjecanje udjela u jednom klubu jest njemačko pravo u kojem se strogo ograničava većinsko sudjelovanje u temeljnom kapitalu kluba - trgovačkog društva. Autonomnim pravom njemačkog nogometnog saveza propisuje se tzv. pravilo , $50+1$ “ po kojemu nijedan ulagač, bez obzira na ulog, ne smije ostvarivati prevladavajući utjecaj u klubu (d.d., d.o.o. i komanditno društvo na dionice njem. $A G$, $G m b H, K G a A$ ) koji je rezerviran za udrugu-majku (njem. Mutterverein). Iznimno to mogu one pravne ili fizičke osobe koje su neprestano potpomagale klub u razdoblju duljem od dvadeset godina, odnosno ukoliko im to odobri Predsjedništvo $D F L$-a.

95 Detaljno obrazloženje razloga koji potvrđuju sportsku, ekonomsku i (neformalno)pravnu povezanost zagrebačkih klubova kao i zaključak da takva prisna povezanost negativno (za ostale klubove) utječe na konačni ishod natjecanja vidi Globan, T., Jägers, E., o. c. u bilj. 44, str. 245-260. 
Radi olakšanja ulaganja i privlačenja ulagača u našem pravu se de lege ferenda predlaže proširiti ustrojbeni oblik kluba na društvo s ograničenom odgovornošću i komanditno društvo, uz istodobno obvezno preoblikovanje udruga. Odredbe o preoblikovanju treba nadopuniti tako da se samo s.d.d. može preoblikovati u d.o.o. ili k.d. i obratno, što bi značilo da se udruga, kao i do sada, može preoblikovati jedino u s.d.d. Udrugama koje se izbore za prvoligaško natjecanje treba dopustiti jednogodišnji rok za pokretanje postupka preoblikovanja. Izrijekom bi trebalo propisati prikladnu primjenu odredbi o ograničenju višestrukih odnosno zabrani isprepletenih udjela na udruge. „Nogometni proizvod“ je vrlo osjetljiv na mogućnost horizontalnog uzajamnog utjecaja klubova međusobno, ili nečijeg izravnog ili neizravnog vertikalnog utjecaja na više klubova, jer se povećava opasnost od ugrožavanja sportske čestitosti koja je temelj, kako povjerenja javnosti i navijača, tako sponzora, medija i ulagača u profesionalni nogomet. Lijek protiv zaraze u hrvatskom profesionalnom nogometu ne treba izmišljati, jer je on sadržan u razmatranim prisilnim odredbama Zakona o sportu. Napokon bi trebali prestati iščekivati Godota i početi na primjeren način primjenjivati postojeći institut višestrukih udjela u cilju zaštite hrvatskog prvoligaškog nogometa. Zbog akutnosti problema HNS bi odredbama svojeg autonomnog prava, primjerice Pravilnikom o nogometnim natjecanjima, trebao spriječiti nečiji izravni ili neizravni utjecaj na više klubova i njihovu horizontalnu povezanost. Nogomet to zaslužuje jer nas zbližava, povezuje domovinsku i iseljenu Hrvatsku i proslavlja našu državu u svijetu, ali i vladavina prava to zaslužuje jer društvo čini uređenijim i harmoničnijim.

\section{PRAVNI IZVORI}

1. Zakon o obveznim odnosima, Narodne novine, br. 35/05, 41/08, 125/111, 78/15, $29 / 18$.

2. Zakon o sportu, Narodne novine br. 17/06, 150/08, 124/10, 124/11, 168/12, 94/13, $85 / 15,19 / 16,98 / 19$.

3. Zakonotrgovačkimdruštvima, Narodnenovine br. 111/93,34/99,121/99-vjerodostojno tumačenje, 52/00- Odluka Ustavnog suda RH, 118/03, 107/07, 146/08, 137/09, $125 / 11,111 / 12,68 / 13,110 / 15,40 / 19$.

4. Zakon o udrugama, Narodne novine br. 74/14, 70/17, 98/19.

5. Ugovor o funkcioniranju Europske unije, Službeni list Europske unije, 17. lipnja 2016., 2016/C, 202/01.

6. Pravilnik o nogometnim natjecanjima, Glasnik HNS-a 24/07- pročiščeni tekst, 09/08, 23/08,9/09, 10/09 - ispravak, 23/09 - pročišćeni tekst,10/10, 15/11, 46/11, 56/11, 19/12, 22/12, 23/12 - ispravak, 28/13, 09/14, 15/14, 60/14, 34/15, 28/16, $51 / 16,05 / 17,45 / 17,37 / 18,55 / 18,22 / 19,29 / 19$ i 09/20.

7. Regulations of the UEFA Champions League, 2018-21 Cycle, dostupno na https:// www.uefa.com/MultimediaFiles/Download/Regulations/uefa.pdf

8. Football Association Rules of Premier Legaue, dostupno na https://resources. premierlegaue.com 
9. Deutsche Fußball Bund - Satzung i Die Liga- Fußballverband e.V-Satzung dostupno na https://www.dfb.de/Fileadmin-Satzung.pdf

10. Presude suda Europske unije: Walrave and Koch, 12. prosinca 1974., C-36/74.; Doná, 14. srpnja 1976., C -13/76.; Höfner, 15. siječnja 1991., C-41/90, Albamy, 21. srpnja 1999., C-67/96.; Bosman, 12. prosinca 1995., C- 415/93.; Lehtonen, 13. travnja 2000., C-176/96.; Deliége, 11. travnja 2000., C-51/96 i C-191/97.; Aéroports de Paris, 24. listopada 2002, C-82/01.; Kolpak, 18. svibnja 2003., C438/00.; Wouters, 22. ožujka 2002., C-309/99.; Simutenkov, 12. travnja 2005., C-265/03.; AEK Athen end Slavia Prag, 20. kolovoza 1999., CAS 98/200.; Meca-Medina, 18. lipnja, 2006 C-519/04.; MOTOE, 1. srpnja 2008., C-49/07.; Olimpique Lyonnais, 16. ožujka 2010., C-325/08.

\section{LITERATURA}

1. Barbić, J., Pravo društava, knjiga prava, Opći dio, Zagreb, 2006.

2. Barbić, J., Pravo društava, Knjiga druga, Društva kapitala, Svezak I., Dioničko društvo, 5. izd., Zagreb, 2010.

3. Bezzenberger, T., Das Kapital der Aktiengesellschaft, Köln, 2005.

4. Brnabić, R., Ivkošić., M., „Novine u pravu preuzimanja dioničkih društava“, Zbornik 52. susreta pravnika, Opatija, 2014., str. 79-123.

5. Ceronja, P., Ivkošić, M., Petrović, S., „Football Club Ownership in the Republic of Croatia: a Model for Suppoters Inclusion in Football Governance in South-East Europe?"“, u Football and Supporter Activism in Europe, Palgrave Macmillian, 2017.

6. Deutcher, J., „50+1-Regelung in der Fußball-Bundesliga- Zur Mehrheitsbeteiligung von Investoren an Fußballklubs“, Zeitschrift für Sport und Recht, 3/2009, str. 97-102.

7. Fritzweiler, J., Pfister, B., Summerer, T., Prexishandbuch Sportrecht, München, 1998.

8. Galli, A., „Profifußbal-(K)ein Geschäft wie jedes andere?“, Zeitschrift für Sport und Recht, 1/20, str. 18-25.

9. Gardiner, S., Sports Law, London, 2001.

10. Gardt, C., „Moderne Finanzirungsmöglikeiten von Fußballverien der 1. FußballBundesliga“, Zeitschrift für Sport und Recht, 1/15, str. 14-19.

11. Globan, T., Jägers, E., „Multiple Ownership, collusion end unusual result; patterns in soccer", Comtemporary Economic Policy, Vol. 37, 2019., 245-260.

12. Hannamann, I., Kartelverbot Verhaltenskoordinationem im Sport, Berlin, 2001.

13. Haas, U., „Applicable Law in football-related dispites - The relationship between the CAS Code, the FIFA Statutes and the agreement of parties on the application of national law", CAS Bullettin, 1/15, str. 10-23.

14. Hennrichs, J. „Kapitalschutz bei GmbH, UG und SPE“, Neue Zeitschrift für Gesellschaftsrecht, 28/2009, str. 290-298.

15. Höfer, C., „Flex-GmbH- eine solvenzorientierte Schwester-Rechtform für die $\mathrm{GmbH}$ ?", Zeitschrift für Gesellschaft-, Unternehmens- und Steuerrecht der GmbH und GmbH \& Co. KG, 8/16, str. 401-412. 
16. Hovemann, G.,,Die 50+1 Regelung aus sportökonomischerund wettbewerbsrechtlicher Sicht“, Zeitschrift für Sport und Recht, 5/2009, str. 188-193.

17. Ivkošić, M., „Gubitak prava glasa-sankcija zbog povrede odredbi o obavješćivanju odnosno preuzimanju dioničkih društava“, Zbornik 55. susreta pravnika, Opatija 2017, str. 345-381.

18. Karch, T., „Der Fußballbundesligaverein als Wirchaftsunternehmen und Arbeitgeber“, Nomos, 2006.

19. Krszesniak, E., J., „Sports Law in Poland“, Kluwer Law International, 2018.

20. Meyer, O., Die Übernahme börsennotierter Aktiengesellschaften nach der UEÜbernahmerichtlinie, Hamburg, 2006.

21. Oschütz, F., ,Sportschidsgerichtbarkeit“, Dunker und Humblot, 2004.

22. Sander, G., Sasadi, A., Sport im Spannungsfeld von Recht, Wirschaft und europäischen Grundfreiheiten, Berlin, 2009.

23. Schaefer, P., „Die Vereinbarkeit der “50+1”- Regel mit dem Europarecht“, Schriften Zum Sportrecht, Nomos, 2012.

24. Schmidt, K., Gesellschaftrecht, Carl Heymanns Verlag, 2002.

25. Scholz Kommentar zum GmbHG, 11. izd., Köln, 2014.

26. Summerer, T., „Investoren für Bundesliga?“, Zeitschrift für Sport und Recht, 6/2008, str. 234-241.

27. Punte, J. H., Die Kapitalgesellschaft als Rechtform profesionaller Fußballklubs im Spannungsfeld von Verbandsautonomie und Europarecht, OIWIR Oldenburg, 2014.

28. Punte, J. H., „Die verbandsrechtliche Baschränkung von Mehrfachbeteiligungen on Fußballklubs durch die UEFA“, Zeitschrift für Sport und Recht, 3/17, str. 94-97.

29. Vieweg, K., Staschik, P., „Lex sportiva und Fairness-Prinzip“, Zeitsschrift für Sport und Recht, 6/2013, str. 225-233.

30. Visković, N., „Državno pravo, autonomna prava i samoupravno pravo“, Arhiv za pravne i društvene nauke, Beograd, 1/1987, str. 2-37.

31. Vezmar Barlek, I., „Primjena načela razmjernosti u praksi Suda Europske unije“, Zbornik Pravnog fakulteta Sveučilišta u Rijeci, v. 38, br. 1, 673-688.

32. Weiler, S. Multy-Club Ownership u Perspektiven des Sportrechts, Berlin, 2005., str. 179.

33. Hovemann, G.,,Die 50+1 Regelung aus sportökonomischerund wettbewerbsrechtlicher Sicht", Zeitschrift für Sport und Recht, 5/2009, str. 173-188.

34. Weiler, S., „Mehrfachbeteilungen an Sportkapitalgesellschaften“, Duncker und Humblot, 2006. 


\section{RESTRICTION OF MULTI-CLUB OWNERSHIP IN PROFESSIONAL FOOTBALL}

In contrast to other business activities, where there exists freedom of investment and acquisition of company stock on the market, in football such options are limited. In all European countries, through national law or on an autonomous level, it is forbidden to horizontally connect football clubs in a way that one club has influence over another. The restriction of multi-club ownership is an essential element in the protection of the integrity of the game. It directly influences the quality of football, as a product, as the dependence of clubs, would directly affect the affection of fans and the interest of the media and sponsors, which in turn affects the interest of investors. After structuring the concept under Croatian and German law, as well as the autonomous rules of the UEFA, the author analyses the adequate application of the rules in Croatia and presents a de lege ferenda viewpoint on how to complement them. The author proposes the introduction of an option to structure clubs as forms of private company limited by shares or limited partnership under national law. This would cause that under the right application of the concept of multi-club ownership restriction, and an increase of the limit to buy out other shareholders in commercial sportsclubs to $50 \%$, cause that foodball clubs become a more attractive investment.

Key words: multiple stocks, controlling share, professional football club, sport stock company, association, investment limitation 